\title{
Area-wide traffic calming for preventing traffic related injuries (Review)
}

\author{
Bunn F, Collier T, Frost C, Ker K, Steinbach R, Roberts I, Wentz R
}

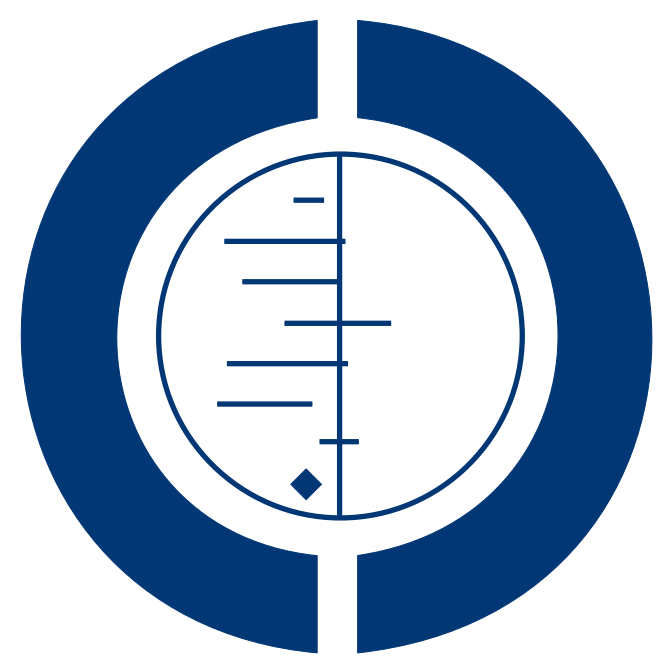

THE COCHRANE COLLABORATION $^{\circledR}$

This is a reprint of a Cochrane review, prepared and maintained by The Cochrane Collaboration and published in The Cochrane Library 2009, Issue 4

http://www.thecochranelibrary.com

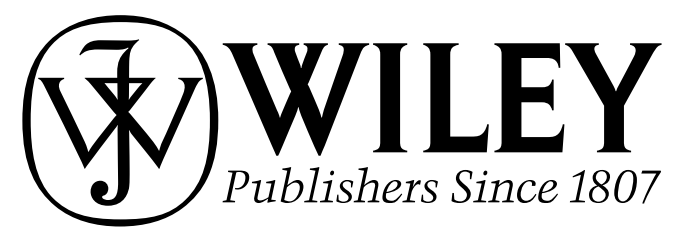

Area-wide traffic calming for preventing traffic related injuries (Review)

Copyright @ 2009 The Cochrane Collaboration. Published by John Wiley \& Sons, Ltd. 
TABLE OF CONTENTS

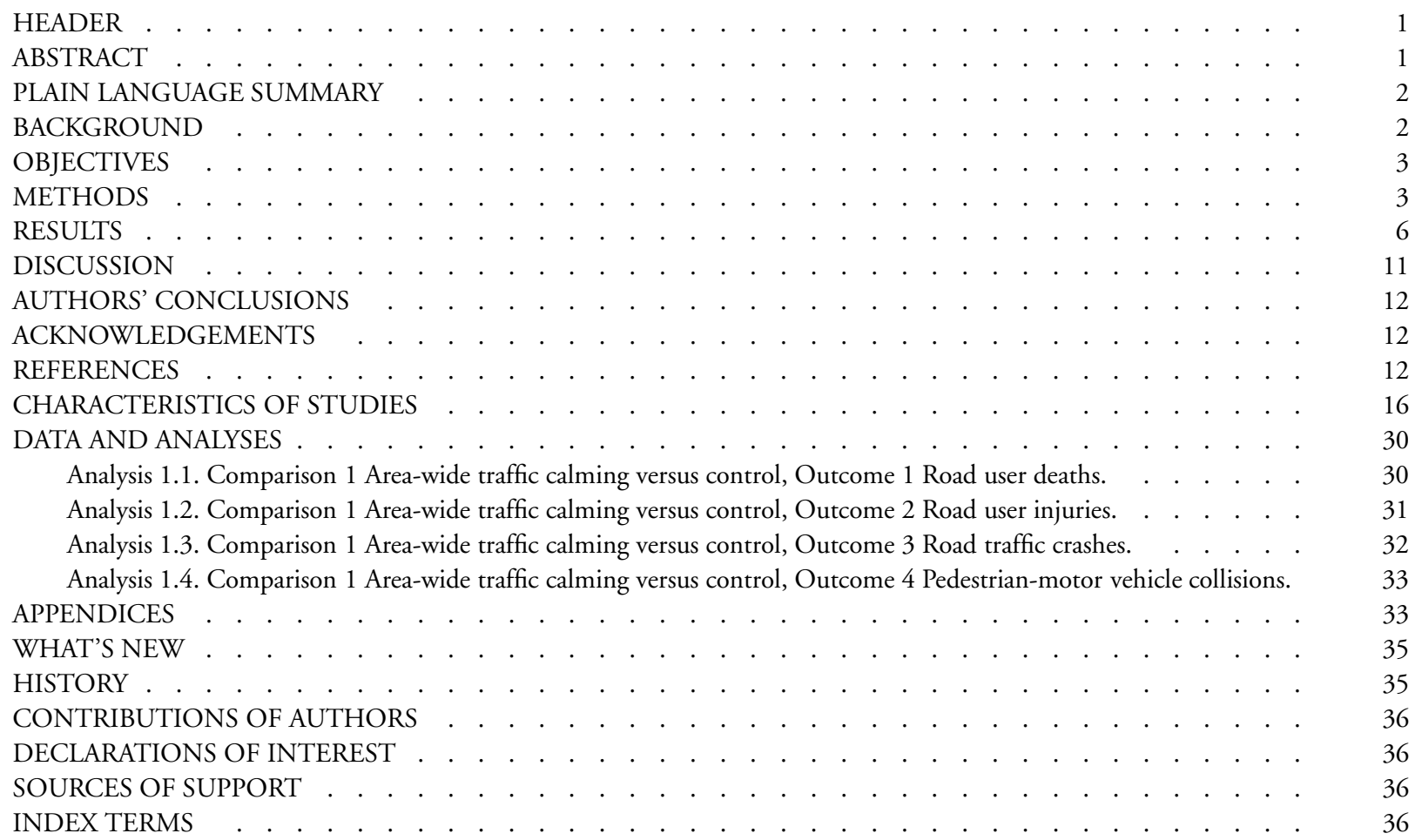




\section{[Intervention Review]}

\section{Area-wide traffic calming for preventing traffic related injuries}

Frances Bunn ${ }^{1}$, Timothy Collier ${ }^{2}$, Chris Frost ${ }^{2}$, Katharine Ker $^{3}$, Rebecca Steinbach ${ }^{4}$, Ian Roberts ${ }^{3}$, Reinhard Wentz ${ }^{5}$

${ }^{1}$ Centre for Research in Primary and Community Care, University of Hertfordshire, Hatfield, UK. ${ }^{2}$ Medical Statistics Unit, London School of Hygiene \& Tropical Medicine, London, UK. ${ }^{3}$ Cochrane Injuries Group, London School of Hygiene \& Tropical Medicine, London, UK. ${ }^{4}$ Public and Environmental Health Research Unit, London School of Hygiene \& Tropical Medicine, London, UK. ${ }^{5}$ Chelsea and Westminster Hospital, London, UK

Contact address: Frances Bunn, Centre for Research in Primary and Community Care, University of Hertfordshire, College Lane, Hatfield, Hertfordshire, AL10 9AB, UK. f.bunn@herts.ac.uk.

Editorial group: Cochrane Injuries Group.

Publication status and date: New search for studies and content updated (no change to conclusions), published in Issue 4, 2009.

Review content assessed as up-to-date: 31 December 2007.

Citation: Bunn F, Collier T, Frost C, Ker K, Steinbach R, Roberts I, Wentz R. Area-wide traffic calming for preventing traffic related injuries. Cochrane Database of Systematic Reviews 2003, Issue 1. Art. No.: CD003110. DOI: 10.1002/14651858.CD003110.

Copyright (c) 2009 The Cochrane Collaboration. Published by John Wiley \& Sons, Ltd.

\section{A B S T R A C T}

\section{Background}

It is estimated that by 2020 road traffic crashes will have moved from ninth to third in the world disease burden ranking, as measured in disability adjusted life years, and to second in developing countries. Area-wide traffic calming schemes that discourage through traffic on residential roads is one strategy for preventing traffic related injuries.

\section{Objectives}

To assess the effects of area-wide traffic calming for preventing traffic related crashes, injuries, and deaths.

\section{Search strategy}

We searched the the Cochrane Injuries Group Specialised Register, Cochrane Central Register of Controlled Trials, MEDLINE, EMBASE and TRANSPORT. We searched the web sites of road safety organisations, handsearched conference proceedings, checked reference lists of relevant papers and contacted experts in the area. The search was not restricted by language or publication status. The searches were last updated in 2008.

\section{Selection criteria}

Randomised controlled trials and controlled before-after studies of area-wide traffic calming schemes.

Data collection and analysis

Two authors independently extracted data on type of study, characteristics of intervention and control areas, and length of data collection periods. Before and after data were collected on the total number of road traffic crashes, all road user deaths and injuries, pedestrianmotor vehicle collisions and road user deaths. The results of each study were expressed as rate ratios.

\section{Main results}

We found no randomised controlled trials, but 22 controlled before-and-after studies met our inclusion criteria. Seven studies were conducted in Germany, seven in the UK, two in Australia, two in the Netherlands, two in Denmark, one in Japan, and one in Spain. There were no studies in low or middle income countries. Nine trials reported the number of road traffic crashes resulting in deaths; pooled rate ratio 0.79 ( $95 \%$ CI 0.23 to 2.68). Eighteen studies reported the number of road traffic crashes resulting in injuries (fatal 
and non-fatal); pooled rate ratio 0.85 (95\% CI 0.75 to 0.96$)$. Twelve studies reported the total number of road traffic crashes; pooled rate ratio 0.89 ( $95 \%$ CI 0.76 to 1.05). Fourteen trials reported the number of pedestrian-motor vehicle collisions; pooled rate ratio 1.01 (95\% CI 0.88 to 1.16$)$. There was evidence of significant heterogeneity for the total number of crashes and road user injuries outcomes.

\section{Authors' conclusions}

The results from this review suggest that area-wide traffic calming in towns and cities may be a promising intervention for reducing the number of road traffic injuries and deaths. However, further rigorous evaluations of such interventions are needed.

\section{PLAIN LANGUAGE SUMMARY}

Area-wide traffic calming (such as introducing road/speed humps) may reduce death and injury from road traffic crashes but more research is needed

Road traffic crashes are a major problem worldwide. In high-income countries, traffic calming schemes aim to make the roads safer (particularly for vulnerable road users such as pedestrians and cyclists) in areas that are particular 'hot spots'. Strategies include slowing down traffic (eg road/speed humps, mini-roundabouts, reduced speed limit zones), visual changes (road surface treatment, changes to road lighting), redistributing traffic (blocking roads, creating one-way streets), and/or changes to road environments (such as trees). This review found that area-wide traffic calming may have the potential to reduce death and injuries, but more research is needed particularly in low and middle income countries.

\section{B A C K G R O U N D}

\section{Description of the condition}

The global epidemic of road traffic deaths and injuries is only just beginning. At present, an estimated 1.23 million people die each year and between 20 and 50 million suffer non-fatal road injuries (WHO 2009). For people under 44 years, road traffic crashes are a leading cause of death and disablement second only to HIV and AIDS (Krug 2002). Moreover, many developing countries are still at comparatively low levels of motorisation and the situation in these countries can only be expected to get worse as motorisation increases. In 1995, road death rates in China were similar to those in the United States, but there were only five vehicles per 1000 population in China compared with 770 vehicles per 1000 in the United States (Roberts 1995). It is estimated that by 2020 road traffic crashes will have moved from ninth to third in the world disease burden ranking, as measured in disability adjusted life years (Murray 1997). Most of the road deaths in developing countries involve vulnerable road users such as pedestrians and cyclists. In Ethiopia, pedestrian injuries account for $84 \%$ of all road traffic fatalities compared with $32 \%$ in Britain and $15 \%$ in the
USA (Barss 1998). In the heavily motorised countries drivers and passengers account for the majority of road deaths but pedestrians account for a large proportion of road deaths involving children. The identification of effective strategies for the prevention of road traffic injuries is of global health importance.

\section{Description of the intervention}

In urban areas many road traffic crashes are scattered widely, and in such situations traditional treatments for high-risk sites are not appropriate. In high income countries, area-wide traffic calming schemes, including the treatment of both main roads and residential roads, have been proposed as one strategy for reducing scattered crashes. Such schemes aim to discourage through traffic on residential roads and make the roads safer, particularly for vulnerable road users such as pedestrians and cyclists.

\section{Why it is important to do this review}

A previous meta-analysis found that area-wide traffic calming schemes on average reduce the number of injury crashes by about 
$15 \%$ (Elvik 2001). However, this study included uncontrolled before-after studies in which the effect of traffic calming could be confounded by the effect of other concurrent changes in road traffic injury rates. For example, in many high income countries pedestrian injury rates have fallen because walking has become a less popular way of travelling. In this case, the inclusion of uncontrolled studies could exaggerate the apparent effect of traffic calming. We conducted a systematic review of area-wide traffic calming including only controlled before-after studies.

\section{O B JE C T IVES}

To assess the effects of area-wide traffic calming measures on the prevention of traffic related injuries.

\section{METHODS}

\section{Criteria for considering studies for this review}

\section{Types of studies}

Studies were included if they involved either of the following research designs:

- Randomised and quasi-randomised controlled trial (RCT)

- Controlled before and after study (CBA)

The definition of CBA is based on that used by the Cochrane Effective Practice and Organisation of Care Group and is given below:

- RCT: A study involving at least one test and one control treatment, concurrent enrolment and follow-up of the test- and control-treated groups, and in which the treatments to be administered are selected by a random process, such as the use of a random numbers table (coin flips are also acceptable). If the author(s) state explicitly (usually by using some variant of the term 'random' to describe the allocation procedure used) that the groups compared in the trial were established by random allocation, then the trial is classified as 'RCT'. Treatment allocations using odd-even numbers, days of the week, or other such pseudo- or quasi-random processes, are designated as quasirandomised.

- CBA: A design where there is contemporaneous data collection before and after the intervention and an appropriate control site or activity.

\section{Types of participants}

Areas covering a number of different streets, including residential and main roads, treated with traffic calming measures.

\section{Types of interventions}

Area-wide traffic calming measures designed to discourage the use of residential streets for through travel; and to create an environment where residential streets are safe. Eligible schemes included those that involved a number of specific named changes to the road layout, road hierarchy, or road environment, such as:

- Vertical and horizontal shifts in traffic (e.g. road humps, speed cushions, raised crosswalks, raised sections of road, chicanes, mini-roundabouts, road narrowing, channelised slip lanes, etc.)

- Optical measures (chevron road sings, road surface treatment (colour, texture), reduced horizontal visibility (shortened sightlines); audible measures (rumble areas, jiggle bars), alterations to road lighting

- Redistribution of traffic or alteration to road hierarchy, (e.g. permanent or temporary blocking of road, diagonal blocks, gateways, creation of one-way streets, re-introduction of two-way streets, four-way stops)

- Changes to road environment (increased vegetation (trees, shrubs) along road, introduction of street furniture).

- Reduced speed limit zones (e.g. 20-mph zones, $30 \mathrm{~km} / \mathrm{h}$ zones) where speeds are physically limited by traffic calming measures.

We excluded studies evaluating single interventions or those looking solely at the following interventions:

- Enforcement of legal interventions (enforcement of speed limits, increased fines for speeding, speed cameras (mock or real), educational programmes aimed at altering driver or pedestrian behaviour, or interventions involving vehicle design changes).

- Fiscal/financial incentives/disincentives (local tolls to reduce extraneous traffic).

- Studies solely describing intervention which separate different road users (cycle lanes, elevated pedestrian walkways, red (bus) lanes etc.).

- Effects of improved public transport facilities.

- Interventions investigating the effect of alterations to road signs or traffic lights alone.

- "Road Diet" interventions (conversions of, for example, four lane undivided roads into three lanes- two through lanes and a centre turn lane).

Comparison of interventions in studies eligible for this review:

- Area-wide traffic engineering intervention versus no intervention

- Area-wide traffic engineering intervention versus legal and/or educational and/or fiscal measures 


\section{Types of outcome measures}

\section{Primary outcomes}

- Road user deaths.

- Road user injuries.

- Road traffic crashes.

- Pedestrian-motor vehicle collisions.

Our definition of 'road users' included all road users not just drivers and occupants of motor vehicles.

\section{Secondary outcomes}

- Perceived quality of urban environment.

- Perceived safety.

\section{Search methods for identification of studies}

\section{Electronic searches}

We searched the following electronic databases;

- Cochrane Injuries Group Specialised Register (searched January 2008),

- Cochrane Central Register of Controlled Trials (The Cochrane Library 2007, Issue 1),

- MEDLINE (to December 2007, week 4)

- EMBASE (to 2008, week 1),

- Sociological Abstracts (to 2000),

- Science (and Social Science) Citation Index,

- TRANSPORT (pre-1980 to 2006 issue 12)

- Psychlit (to 2000),

- National Research Register (2007, Issue 1),

- International Bibliography of the Social Sciences (1951 to 2007/10)

The search strategies used for the updated searches performed in 2007/08 are presented in Appendix 1; Appendix 2; Appendix 3; Appendix 4; Appendix 5.

We searched the web sites of the following road safety organisations (searches performed in 2001):

- AAA Foundation for Traffic Safety (USA) -

www.aaafoundation.org

- ARRB - Australian Road Research Board - www.arrb.org.au

- Australian Transport Safety Bureau - www.atsb.gov.au

- CROW - Information and Technology Centres for

Transport and Infrastructure (Netherlands) - www.crow.nl

- Danish Council for Road Safety Research - www.trm.dk/ $\mathrm{eng} / \mathrm{veje} / \mathrm{rft}$

- Danish Transport Research Institute - www.dtf.dk
- DETR -www.detr.gov.uk/

- DVR - Deutscher Verkehrssicherheitsrat Road Safety Institute (Germany) - www.dvr.de/

- FINNRA - Finnish National Road administration www.tieh.fi

- INRETS - Institut National de Recherche sur les Transports et leur Sécurité (France) - www.inrets.fr

- ITE - Institute of Transportation Engineers (USA) www.ite.org

- LET - Laboratoire d'economie des transports (France) www.lsh-lyon.cnrs.fr

- NHTSA - National Highway Traffic Safety Administration (USA) - www.nhtsa.dot.gov

- Swedish National Roads Administration - www.vv.se/for_ lang/english/

- SWOV - Institute for Road Safety Research (Netherlands) www.swov.nl

- TOI - Institute of Transport Economics (Norway) www.toi.no

- TC - Transport Canada - www.tc.gov

- TRB- Transportation Research Board- www.nas.edu/trb/

- TRL- Transport Research Laboratory (UK) - www.trl.co.uk

- US Department of Transport - Federal Highway

Administration (USA) - www.fhwa.dot.gov

- VTI - Swedish National Road and Transport Research Institute - www.vti.se

- VTT - Finland www.vtt.fi/indexe.htm

\section{Searching other resources}

We handsearched the following conference proceedings:

- Australian Road Research Board (ARRB). Proceedings of the 12th ARRB conference, Hobart Tasmania 27th to 31st August 1984.

- Australian Road Research Board (ARRB). Proceedings of the 15th ARRB conference, Darwin, 26th to 31 August 1990.

- Institution of Professional Engineers New Zealand (IPENZ). Annual conference Christchurch February 1992 Volumes $1 \& 2$.

- Institution of Professional Engineers New Zealand (IPENZ). Proceedings of the technical session of the group at the annual conference of IPENZ, Auckland 8th to 12th February 1982.

- Institute of Transportation Engineers (ITE). Proceedings of the 45th to 71 st ITE annual meeting, 1975 to 2001.

- Institute of Transportation Engineers (ITE). Transportation and traffic theory 9th international symposium, Netherlands 1984.

- Institute of Transportation Engineers (ITE). Residential street design and traffic control 1989.

- Israel Institute of technology. International conference on pedestrian safety. Haifa 20th to 23rd December 1976. 
- Landor Publishing Ltd. The third national traffic calming conference. London 18th October 1996.

- Organisation for economic co-operation and development (OECD). Proceedings of the symposium on techniques of improving urban conditions by restraint of road traffic; 25 th to 27th October 1971.

- PTRC Transport, Highways and Planning Summer 13th to 18th Annual Meetings, 1985-1990.

- Swedish Road and Traffic Research Institute. Proceedings of the conference on strategic highway research program and traffic safety on two continents; Gothenburg Sweden, September 18th to 20th, 1991.

- Swedish Road and Traffic Research Institute. Proceedings of the conference on strategic highway research program and traffic safety on two continents; Gothenburg Sweden, September 27th to 29th, 1989.

- Swedish Road and Traffic Research Institute. Proceedings of the conference on road safety and traffic environment in Europe, Gothenburg Sweden, September 26th to 28th, 1990.

- The Technion Israel Institute of Technology. The second international conference on new ways for improved road safety and quality of life, 7th to 10th October 1991, Tel-Aviv Hilton Hotel, Israel.

- Transportation Research Institute. International conference on new ways and means for improved safety, Tel Aviv, Israel, Feb 20th to 23rd 1989.

- Transport Research Laboratory. Safety 91 Papers on vehicle safety, traffic safety and road user safety research, TRL

Laboratory Berks 1st to 2nd May 1991.

We identified further potential published or unpublished studies by checking references of relevant papers and reviews; contacting authors of relevant papers; and contacting international road safety organisations.

\section{Data collection and analysis}

\section{Selection of studies}

One author examined titles, abstracts, and keywords of citations, as given on electronic databases, for eligibility. Where possible, we obtained the full text of all possible relevant citations. One author decided whether studies met the inclusion criteria, and this was checked by a second author.

\section{Data extraction and management}

Two authors independently extracted data from each eligible study using a standard form. Data were extracted on the type of study (e.g. RCT, CBA), characteristics of intervention and control areas, the types of intervention, duration of follow up and the outcomes evaluated. Differences found in data extraction were resolved by discussion. Where necessary, we sought additional information from researchers involved in the studies.

\section{Assessment of risk of bias in included studies}

The assessment of the quality of non-randomised trials is problematic. Controlled before-after studies are recognised to be methodologically weaker than randomised controlled trials, and few quality assessment tools exist. In this review we assessed the quality of the CBAs by extracting data on how well the intervention and control areas were matched, and the length of the before and after data collection periods. Because of the potential for contamination, we also noted the distance between the intervention and control areas.

\section{Measures of treatment effect}

The results of each study are expressed as rate ratios. The rate ratio is the ratio of event rates post and pre intervention in the intervention area divided by the corresponding post to pre intervention event ratio in the control area. Provided that any changes in the population at risk are the same in both control and intervention areas, the rate ratio gives the reduction in the event rate in the intervention area compared to that in the control area. For example, a rate ratio of 0.8 corresponds to a $20 \%$ reduction in events in the intervention area compared to that predicted from the rates in the control area.

We calculated standard errors for logarithms of rate ratios and hence $95 \%$ confidence intervals for rate ratios, assuming that the number of events in each area in each period followed a Poisson distribution.

\section{Assessment of heterogeneity}

We examined statistical heterogeneity by using both the I-squared and $\mathrm{Chi}^{2}$ tests. The $\mathrm{I}^{2}$ test describes the percentage of total variation across studies due to heterogeneity rather than chance. A value of $0 \%$ indicates no observed heterogeneity, and larger values show increasing heterogeneity; substantial heterogeneity is considered to exist when $\mathrm{I}^{2}>50 \%$ (Higgins 2008). For the $\mathrm{Chi}^{2}$ statistic, we used a $\mathrm{P}$ value of $<0.10$ to indicate the presence of statistically significant heterogeneity.

\section{Data synthesis}

Using the generic inverse variance method in Review Manager, we combined the rate ratios on a logarithmic scale using a random effects meta-analysis model. The assumption of random effects both allows for the anticipated heterogeneity between effects across studies and provides robustness if the assumption that events follow Poisson distributions is violated through overdispersion. 
In the analysis of road user deaths, where the majority of studies had no events in at least one period, no test of heterogeneity was carried out and a pooled estimate of the rate ratio was obtained from the column totals. The confidence interval for this estimate would, in expectation, be too narrow since the method ignores the likely heterogeneity between studies. However, under the circumstances of many zero observations, this method has some advantage over the alternative of adding 0.5 when observing zero.

\section{R E S U L T S}

\section{Description of studies}

See: Characteristics of included studies; Characteristics of excluded studies; Characteristics of ongoing studies.

\section{Results of the search}

Our searches identified 13,520 published and unpublished reports. We obtained the full text of 635 reports and of these 22 controlled before-after studies met our inclusion criteria (Charlottenburg 1990; Denmark 1992; GST-Buxtehude 1993; GST-Esslingen 1993; GST-Borgentreich 1993; GSTIngolstadt 1993; GST-Mainz 1993; GST-Moabit 1993; London 2007; Madrid 2006; Mørkhøj 2001; Osaka 1998; Rijswijk/ Eindhoven 1991; Swindon 1981; Sydney-Canterbury 1990; Sydney-Willoughby 1990; The Netherlands 1992; USP Bradford 1989; USP Bristol 1989; USP Nelson 1989; USP Reading 1989; USP Sheffield 1989). We found no randomised controlled trials.

\section{Included studies}

In all the studies in this review the areas involved were predominantly residential, often located close to the central commercial sector of a large town or city. Area-wide traffic calming involved a reclassification of the streets in the area, aiming to move through traffic away from residential streets and concentrate it on roads that were classified as main roads. In all studies a combination of traffic calming measures was used, including interventions such as road closures, changes to junctions, changes to the road environment (for example with traffic humps or chicanes), improvement in pedestrian crossing facilities and the use of miniroundabouts. Seven studies were conducted in Germany (GSTBorgentreich 1993; GST-Buxtehude 1993; Charlottenburg 1990; GST-Esslingen 1993; GST-Mainz 1993; GST-Moabit 1993; GST-Ingolstadt 1993), seven in the UK (London 2007; Swindon 1981; USP Bradford 1989; USP Bristol 1989; USP Nelson 1989; USP Reading 1989; USP Sheffield 1989), two in Australia ( Sydney-Canterbury 1990; Sydney-Willoughby 1990), two in the Netherlands (Rijswijk/Eindhoven 1991; The Netherlands 1992), two in Denmark (Denmark 1992; Mørkhøj 2001), one in Japan ( Osaka 1998), and one in Spain (Madrid 2006). One of the German studies (Charlottenburg 1990) was a pilot scheme for the other six German towns; Borgentreich, Buxtehude, Esslingen, Mainz, Moabit, and Ingolstadt. One of the studies in the UK (Swindon 1981) was a pilot scheme for the other five Urban Safety Project towns; Bradford, Bristol, Nelson, Reading and Sheffield. The two Australian studies both took place in Sydney.

More details about individual studies can be found in the Characteristics of included studies table.

\section{Risk of bias in included studies}

As there is not an accepted instrument for appraising the quality of controlled before-after-studies we have not attempted a formal quality score or appraisal of the studies. Where possible we collected information on:

- the length of data collection before and after the intervention;

- how intervention and control areas were matched; and

- proximity of control area to intervention area.

Berlin Charlottenburg (Charlottenburg 1990):

A controlled before-after study with two years before and two years after data. Berlin Moabit was chosen as the control area. Little information was given about the control area. Data on the number of crashes and injuries were collected from police records. Incidence of crashes and injuries in the before period were much higher in the control area than the intervention area.

Denmark 1992:

A controlled before-after study with three years before data and three years after data. The control areas were selected to match the intervention areas. There was no significant difference in the mean speeds of motor vehicles in the control and intervention areas. German six towns study (GST-Esslingen 1993; GST-Ingolstadt 1993; GST-Mainz 1993; GST-Moabit 1993; GST-Borgentreich 1993; GST-Buxtehude 1993):

Controlled before-after studies with two years before data and two years after data; except for Borgentreich where the after period was extended to three years to obtain a sufficient sample size. The controlled areas for each town are in brackets. Berlin-Moabit (Berlin-Wedding), Borgentreich (Borgholz), Buxtehude (Buxtehude-Sud), Esslingen (Nurtingen), Ingolstadt (Regensburg), Mainz-Bretzenheim (Mainz-Finthen). Data on the number of crashes and injuries were collected from police records. The criteria for choosing the control areas were:

- similar sized cities;

- same region of Germany;

- similar structure to the area under study;

- no traffic calming measures;

- availability of data from police records; and 
- readiness of the city authorities to co-operate.

N.B. additional information provided by one of the study authors. London 2007:

A controlled before-after study with five years of before data on both the intervention and control group, between one and five years of after data on the intervention group, and three years of after data on the control group. The control roads were all unclassified roads in London.

Madrid 2006:

A controlled before-after study with two years of before data and two years of after data. The control areas and intervention areas were similar in that they both belonged to the highway network of the Autonomous Community of Madrid and both eventually received traffic calming. The control areas received traffic calming at a later date than the intervention areas.

Mørkhøj 2001:

A controlled before-after study with three years of before data and three years of after data. The control area was the remainder of the municipality where the intervention was situated. No other information was given about the control area.

Osaka 1998:

A controlled before-after study with six years of before data and six years of after data. No other information was given on the control areas.

Rijswijk/Eindhoven 1991:

A controlled before-after study with six years before data and five years after data. The control and intervention areas were similar in that they were both residential districts, built before 1972, with adjacent main traffic arteries. To avoid contamination the control areas were not in the immediate vicinity of the demonstration areas. Data on the number of crashes and injuries were collected from police records.

Swindon 1981:

A controlled before-after study with four years before data and two years after data. The controls chosen were similar routes where the local council agreed as far as possible to keep roadworks to a minimum. However, the authors note that the 'behaviour' of the control routes was not typical of other types of roads in Swindon during the two year after period. They concluded that the control technique had broken down. Data on the number of crashes and injuries were collected from County Council records.

Sydney-Canterbury 1990:

A controlled before-after study with three years before data and two and a half years after data. Although efforts were made to match the control and intervention areas they had different land use characteristics and, unlike the intervention area, the control had no industrial zone. Areas were of a similar size. The areas were close but not immediately adjacent. Data on the number of crashes and injuries were collated from the Traffic Authority of New South Wales records. There was a lower incidence of crashes and injuries in the before period in the intervention area, than in the before period in the control area.

Sydney-Willoughby 1990:

Controlled before-after study with two years before data and two years after data. The control area was selected because of its similar traffic problems to the intervention area, although it did not reflect the grid pattern of the study area. Areas were of a similar size.

Data on the number of crashes and injuries were collected from the records of the Traffic Authority of New South Wales.

In the before period the incidence of crashes was much higher in the intervention area than in the control area.

The Netherlands 1992:

A controlled before-after study with three years before data and three years after data. The control areas were roads in built-up areas, excluding arterial roads, in the same municipalities that the intervention areas were situated in.

Urban Safety Project (USP Bradford 1989; USP Bristol 1989; USP Nelson 1989; USP Reading 1989; USP Sheffield 1989):

These were controlled before after studies with matched comparison groups. For each town a five year 'before' period was used to detect trends and seasonal variation in the crash pattern and so to establish a range of crashes that might be expected in the 'after' period had the project not taken place. Two years of after data were collected. Any differences in crash-rate between the 'before' and 'after' periods was taken to be due to a combination of system-wide secular effects, random effects and the effects of the scheme itself. The criteria used for choosing the areas in the project were that they were of average risk, had a range of residential network types, and were large enough to show the interaction between main road and residential road traffic redistribution. A second area with similar crash and network characteristics was chosen for the control. The areas were not immediately adjacent. Data on the number of crashes and injuries were collected from police records. Incidence of crashes and injuries in the intervention and control areas were fairly well matched for the before period.

\section{Effects of interventions}

\section{Road user deaths}

Nine studies reported the number of road traffic crashes resulting in deaths (Denmark 1992; GST-Borgentreich 1993; GSTBuxtehude 1993; GST-Esslingen 1993; GST-Ingolstadt 1993; GST-Mainz 1993; GST-Moabit 1993; Sydney-Canterbury 1990; Sydney-Willoughby 1990). The pooled rate ratio was 0.79 (95\% CI 0.23 to 2.68), which was calculated from the column totals, due to zero counts observed in a number of the studies. Individual results for each study are presented in Table 1 . The results should be interpreted with caution; the method of using the column totals to calculate the rate ratio ignored the likely heterogeneity between the studies, and the estimate is likely to be too narrow. 
Table 1. Road user deaths

\begin{tabular}{l|lllll}
\hline Study ID & $\begin{array}{l}\text { Intervention } \\
\text { before }\end{array}$ & Intervention after & Control before & Control after & Rate ratio (95\% CI) \\
\hline Denmark & 0 & 1 & 1 & 0 & Undefined \\
\hline GST-Moabit & 7 & 3 & 12 & 7 & $0.73(0.14$ to 3.80) \\
\hline GST-Borgentreich & 0 & 0 & 0 & 1 & Undefined \\
\hline GST-Buxtehude & 0 & 0 & 0 & 1 & Undefined \\
\hline GST-Esslingen & 3 & 0 & 3 & 2 & Undefined \\
\hline GST- Ingolstadt & 0 & 0 & 0 & 0 & Undefined \\
\hline GST-Mainz & 1 & 0 & 0 & 1 & Undefined \\
\hline Sydney-Canterbury & 1 & 0 & 2 & 1 & Undefined \\
\hline Sydney-Willoughby & 0 & & 2 & Undefined \\
\hline
\end{tabular}

\section{Road traffic injuries (fatal and non fatal)}

Eighteen studies (Charlottenburg 1990; Denmark 1992; GSTBorgentreich 1993; GST-Buxtehude 1993; GST-Esslingen 1993; GST-Ingolstadt 1993; GST-Mainz 1993; GST-Moabit 1993; London 2007; Rijswijk/Eindhoven 1991; Swindon 1981; SydneyCanterbury 1990; Sydney-Willoughby 1990; USP Bradford 1989; USP Bristol 1989; USP Nelson 1989; USP Reading 1989; USP Sheffield 1989) reported the number of road traffic crashes resulting in injuries. The pooled rate ratio was 0.85 (95\% CI 0.75 to 0.96). Individual results for each trial can be seen in Table 2 . There was significant statistical heterogeneity between trials (Chi $\left.2=52.24, \mathrm{df}=17, \mathrm{P}=<0.0001, \mathrm{I}^{2}=67 \%\right)$.

Table 2. Road user injuries

\begin{tabular}{|c|c|c|c|c|c|}
\hline Study & $\begin{array}{l}\text { Intervention } \\
\text { before }\end{array}$ & Intervention after & Control before & Control after & Rate Ratios (95\% CI) \\
\hline Charlottenburg & 31 & 11 & 95 & 71 & $0.47(0.22$ to 1.01$)$ \\
\hline Denmark & 40 & 13 & 19 & 17 & $0.36(0.15$ to 0.90$)$ \\
\hline GST-Borgentreich & 17 & 10 & 6 & 4 & $0.88(0.20$ to 3.90$)$ \\
\hline GST-Buxtehude & 40 & 41 & 96 & 61 & $1.61(0.94$ to 2,77$)$ \\
\hline
\end{tabular}


Table 2. Road user injuries (Continued)

\begin{tabular}{|c|c|c|c|c|c|}
\hline GST-Esslingen & 103 & 90 & 91 & 82 & $0.97(0.64$ to 1.46$)$ \\
\hline GST-Ingolstadt & 185 & 139 & 272 & 182 & $1.12(0.84$ to 1.50$)$ \\
\hline GST-Mainz & 27 & 13 & 63 & 30 & 1.01 (0.46 to 2.23$)$ \\
\hline GST-Moabit & 275 & 228 & 379 & 392 & $0.80(0.64$ to 1.00$)$ \\
\hline London & 387 & 208 & 7012 & 6811 & $0.55(0.47$ to 0.66$)$ \\
\hline Rijswijk/Eindhoven & 923 & 458 & 4453 & 3069 & $0.72(0.64$ to 0.81$)$ \\
\hline Swindon & 197 & 89 & 115 & 74 & $0.70(0.48$ to 1.03$)$ \\
\hline Sydney-Canterbury & 76 & 73 & 101 & 116 & 0.84 ( 0.55 to 1.27$)$ \\
\hline Sydney-Willoughby & 74 & 69 & 20 & 19 & 0.98 (0.48 to 1.99$)$ \\
\hline USP Bradford & 551 & 190 & 629 & 232 & $0.93(0.75$ to 1.17$)$ \\
\hline USP Bristol & 693 & 231 & 647 & 206 & 1.05 (0.84 to 1.30$)$ \\
\hline USP Nelson & 539 & 180 & 634 & 228 & 0.93 (0.74 to 1.16$)$ \\
\hline USP Reading & 714 & 303 & 653 & 257 & 1.08 (0.89 to 1.31$)$ \\
\hline USP Sheffield & 636 & 181 & 520 & 214 & $0.69(0.55$ to 0.87$)$ \\
\hline
\end{tabular}

\section{Road traffic crashes}

Twelve studies (Charlottenburg 1990; GST-Borgentreich 1993; GST-Buxtehude 1993; GST-Esslingen 1993; GST-Ingolstadt 1993; GST-Mainz 1993; GST-Moabit 1993; London 2007; Mørkhøj 2001; Osaka 1998; Sydney-Canterbury 1990; SydneyWilloughby 1990) reported the total number of road traffic crashes. The pooled rate ratio was 0.89 (95\% CI 0.76 to 1.05 ). Individual results for each trial can be seen in Table 3. There was significant statistical heterogeneity between trials $\left(\mathrm{Chi}^{2}=74.59\right.$, $\left.\mathrm{df}=11, \mathrm{P}=<0.00001, \mathrm{I}^{2}=85 \%\right)$.

Table 3. Road traffic crashes

\begin{tabular}{|c|c|c|c|c|c|}
\hline Study & $\begin{array}{l}\text { Intervention } \\
\text { before }\end{array}$ & Intervention after & Control before & Control after & Rate Ratios (95\% CI) \\
\hline Charlottenburg & 172 & 115 & 400 & 357 & $0.75(0.57$ to 0.99$)$ \\
\hline
\end{tabular}


Table 3. Road traffic crashes (Continued)

\begin{tabular}{|c|c|c|c|c|c|}
\hline GST-Borgentreich & 62 & 82 & 23 & 17 & 1.79 (0.88 to 3.63$)$ \\
\hline GST-Buxtehude & 537 & 629 & 349 & 438 & 0.93 (0.78 to 1.12$)$ \\
\hline GST-Essligen & 887 & 982 & 434 & 413 & $1.16(0.99$ to 1.37$)$ \\
\hline GST-Ingolstadt & 1015 & 876 & 957 & 627 & $1.32(1.15$ to 1.51$)$ \\
\hline GST-Mainz & 569 & 473 & 358 & 342 & $0.87(0.72$ to 1.05$)$ \\
\hline GST-Moabit & 1902 & 2026 & 2089 & 2745 & $0.81(0.74$ to 0.88$)$ \\
\hline London & 322 & 188 & 6022 & 5800 & $0.61(0.50$ to 0.73$)$ \\
\hline Mørkhøj & 16 & 1 & 310 & 158 & $0.12(0.01$ to 0.93$)$ \\
\hline Osaka & 45 & 39 & 20 & 20 & $0.87(0.41$ to 1.84$)$ \\
\hline Sydney-Canterbury & 217 & 201 & 312 & 347 & 0.83 (0.65 to 1.06$)$ \\
\hline Sydney-Willoughby & 229 & 271 & 61 & 98 & $0.74(0.51$ to 1.06$)$ \\
\hline
\end{tabular}

\section{Pedestrian-motor vehicle collisions}

Fourteen trials reported the number of pedestrian crashes (GSTBorgentreich 1993; GST-Buxtehude 1993; GST-Esslingen 1993; GST-Ingolstadt 1993; GST-Mainz 1993; GST-Moabit 1993; Osaka 1998; Sydney-Canterbury 1990; Sydney-Willoughby 1990; USP Bradford 1989; USP Bristol 1989; USP Nelson 1989; USP Reading 1989; USP Sheffield 1989). The pooled rate ratio was 1.01 (95\% CI 0.88 to 1.16). Individual results for each trial can be seen in Table 4 . The results should be interpreted with caution; the method of using the column totals to calculate the rate ratio ignored the likely heterogeneity between the studies, and the estimate is likely to be too narrow.

Table 4. Pedestrian-motor vehicle collisions

\begin{tabular}{|c|c|c|c|c|c|}
\hline Study & $\begin{array}{l}\text { Intervention } \\
\text { before }\end{array}$ & Intervention after & Control before & Control after & Rate ratios $(95 \% \mathrm{CI})$ \\
\hline GST-Borgentreich & 3 & 1 & 0 & 0 & Undefined \\
\hline GST-Buxtehude & 26 & 13 & 24 & 16 & 0.75 (0.30 to 1.88$)$ \\
\hline GST-Esslingen & 50 & 36 & 12 & 12 & $0.72(0.29$ to 1.78$)$ \\
\hline
\end{tabular}


Table 4. Pedestrian-motor vehicle collisions (Continued)

\begin{tabular}{|c|c|c|c|c|c|}
\hline GST-Ingolstadt & 56 & 32 & 105 & 75 & $0.80(0.47$ to 1.35$)$ \\
\hline GST-Mainz & 13 & 9 & 18 & 7 & 1.78 (0.53 to 6.02$)$ \\
\hline GST-Moabit & 179 & 143 & 179 & 142 & $1.10(0.74$ to 1.37$)$ \\
\hline Osaka & 12 & 6 & 5 & 3 & 0.83 (0.15 to 4.72$)$ \\
\hline USP-Bradford & 174 & 65 & 231 & 78 & $1.11(0.75$ to 1.62$)$ \\
\hline USP-Bristol & 136 & 67 & 170 & 45 & $1.86(1.20$ to 2.89$)$ \\
\hline USP-Nelson & 219 & 80 & 267 & 103 & $0.95(0.67$ to 1.33$)$ \\
\hline USP-Reading & 173 & 73 & 116 & 48 & 1.02 (0.66 to 1.57$)$ \\
\hline USP-Sheffield & 248 & 68 & 206 & 83 & 0.68 (0.47 to 0.99$)$ \\
\hline Sydney-Canterbury & 9 & 9 & 17 & 20 & $0.85(0.28$ to 2.63$)$ \\
\hline Sydney-Willoughby & 8 & 12 & 1 & 0 & Undefined \\
\hline
\end{tabular}

\section{Perceived safety}

Two trials looked at residents' perceptions of safety before and after the schemes. In one (Sydney-Willoughby 1990), almost 80\% of those who responded (response rate of $43 \%$ ) supported the council's policy of improving residential safety by reducing the volume of through traffic. However, only $64 \%$ supported the permanent installation of the trial scheme. In the other study (SydneyCanterbury 1990), the majority of residents who responded (65\%) felt that the level of safety had remained constant or diminished.

\section{DISCUSSION}

\section{Summary of main results}

The results of this systematic review of controlled before-after studies shows that area-wide traffic calming schemes may have the potential to reduce road traffic deaths and injuries. Although the effect on road traffic injury deaths alone was in the same direction and of a similar magnitude, the number of road deaths in the included studies was low, and the estimate is likely to be too narrow since the method used ignored the likely heterogeneity between the studies. As very few studies reported the number of deaths and injuries for the different categories of road user (pedestrians, cyclists and vehicle occupants) it was not possible to examine the effect of traffic calming by road user category. Although there was no evidence that traffic calming schemes prevent pedestrian-motor collisions, the possibility that they might reduce the occurrence of pedestrian injury cannot be excluded. An important effect of traffic calming schemes is to reduce the speed of traffic, in which case traffic calming might still reduce the likelihood of injury in the event of a collision.

\section{Overall completeness and applicability of evidence}

Road traffic crashes are a major cause of death and injury in low and middle income countries. With increasing motorisation in these countries the problem is likely to get worse. In low income countries the majority of casualties are not motor vehicle occupants; they are pedestrians, cyclists and riders of motorised two-wheelers. Compared to educationally based road safety interventions, areawide traffic calming appears to be a more promising intervention 
for reducing traffic injuries and deaths. However, further rigorous evaluation is required, particularly in middle and lower income countries.

\section{Quality of the evidence}

The validity of a systematic review also depends importantly on the validity of the included studies. Although we found no randomised controlled trials of traffic calming schemes, the inclusion of studies with well matched intervention and control areas, with adequate before and after periods, may avoid the problem of confounding by changes in the background rate of injury. All of the included studies collected at least one year before and two years after data, with a number collecting up to six years of before or after data.

\section{Potential biases in the review process}

There are a number of methodological issues that could have an important bearing on the validity of these results. Publication and other selection biases are a potential threat to validity in all systematic reviews but this is a particular problem in road safety where a large proportion of the available research information is published in the grey literature of the road safety research organisations. There are also problems identifying the published controlled studies in the road safety databases (Wentz 2001). Search strategies for identifying controlled studies in medical databases can achieve high sensitivity and positive predictive value because terms describing the study methodology are included among the indexing (descriptor) terms. Road safety databases however, have a very limited range of indexing terms describing the study methodology. Because of these problems we used only limited methodological search terms when searching the TRANSPORT databases but screened all studies of traffic calming schemes for eligibility. Nevertheless, despite our considerable efforts to identity all eligible studies, published and unpublished and irrespective of language of publication, we cannot exclude the possibility of selection bias. Although we chose to pool the data in a random effects metaanalysis, because there was significant heterogeneity for both the pooled number of road traffic crashes and the number of road traffic crashes resulting in injuries, these results should be interpreted with caution. The observed heterogeneity may be due to differences in study design, differences in the types of traffic calming schemes involved, or to differences in the way outcomes were defined and data collected. There was no evidence of statistical heterogeneity for the other outcomes, death and pedestrian motorvehicle collisions. However, it is still plausible that heterogeneity did exist as there is no reason to assume that differences between studies would cause heterogeneity for some outcomes but not for others.

\section{A U THORS' CONCLUSIONS}

\section{Implications for practice}

Area-wide traffic calming appears to be a promising intervention for reducing traffic injuries and deaths in towns and cities. However, further rigorous evaluation is needed before we can answer the question conclusively.

\section{Implications for research}

In searching for studies of traffic calming we found numerous uncontrolled before-after studies but only 22 controlled beforeafter studies and no randomised controlled trials. Traffic calming interventions need to be properly evaluated using well-designed controlled studies, so that we can more accurately estimate their effects. In addition, researchers need to assess the effect of these interventions in middle and lower income countries.

\section{ACKNOWLEDGEMENTS}

Thanks to Rob Sholten, Kirsten Lone Jensen, Mattias Svensson, Emma Sydenham and Mirna Holle for help with translation, to Irene Kwan for help with handsearching and to Fiona Renton and Karen Blackhall for help locating papers.

\section{REFERENCES}

\section{References to studies included in this review}

Charlottenburg 1990 \{published data only\}

Brilon W, Blanke H. Traffic safety effects from traffic calming. VTI

Rapport. Vol. 363A, 1990:133-48.

Kahrmann B. [Area-wide traffic restraint measures: Analysis of accidents in Berlin-Charlottenburg]. 2nd International conference on road safety Groningen, Netherlands 31/8/87-4/9/87. 1988: $424-34$.
Column totals \{published data only\}

Denmark 1992 \{published data only\} Engel U, Thomsen LK. Safety effects of speed reducing measures in Danish residential areas. Accident Analysis and Prevention 1992;24 (1):17-28.

GST-Borgentreich 1993 \{published data only\}

* Blanke H. Speed behaviour and traffic security at regionally smoothed traffic [Geschwindigkeitsverhalten und 
Verkehrssicherheit bei flachenhafter Verkehrsberuhigung]. RuhrUniversitat Bochum. 1993:335.

Brilon W, Blanke H. [Extensive traffic calming: results of the accident analyses in 6 model towns]. ITE Compendium of technical papers. Washington DC, 1993:119-23.

Brilon W, Blanke $\mathrm{H}$. Traffic safety effects from traffic calming. VTI Rapport. Vol. 363A, 1990:133-48.

\section{GST-Buxtehude 1993 \{published data only\}}

* Blanke H. Speed behaviour and traffic security at regionally smoothed traffic [Geschwindigkeitsverhalten und

Verkehrssicherheit bei flachenhafter Verkehrsberuhigung]. RuhrUniversitat Bochum. 1993:335.

Brilon W, Blanke H. [Extensive traffic calming: results of the accident analysis in 6 model towns]. ITE compendium of technical papers. 1993:119-23.

Brilon W, Blanke H. Traffic safety effects from traffic calming. VTI Rapport. Vol. 363A, 1990:133-48.

\section{GST-Esslingen 1993 \{published data only\}}

* Blanke H. Speed behaviour and traffic security at regionally smoothed traffic [Geschwindigkeitsverhalten und Verkehrssicherheit bei flachenhafter Verkehrsberuhigung]. RuhrUniversitat Bochum. 1993:335.

Brilon W, Blanke H. [Extensive traffic calming: results of the accident analysis in 6 model towns]. ITE Compendium of technical papers. Washington DC, 1993:119-23.

Brilon W, Blanke $\mathrm{H}$. Traffic safety effects from traffic calming. VTI Rapport. Vol. 363A, 1990:134-49.

\section{GST-Ingolstadt 1993 \{published data only\}}

* Blanke H. Speed behaviour and traffic security at regionally smoothed traffic [Geschwindigkeitsverhalten und Verkehrssicherheit bei flachenhafter Verkehrsberuhigung]. RuhrUniversitat Bochum. 1993:335.

Brilon W, Blanke H. [Extensive traffic calming: results of the accident analyses in 6 model towns]. ITE Compendium of technical papers. Washington DC, 1993:119-23.

Brilon W, Blanke H. [Traffic safety effects from traffic calming]. VTI Rapport. Vol. 363A, 1990:134-49.

\section{GST-Mainz 1993 \{published data only\}}

Blanke H. Speed behaviour and traffic security at regionally smoothed traffic [Geschwindigkeitsverhalten und Verkehrssicherheit bei flachenhafter Verkehrsberuhigung]. RuhrUniversitat Bochum. 1993:335.

\section{GST-Moabit 1993 \{published data only\}}

* Blanke H. Speed behaviour and traffic security at regionally smoothed traffic [Geschwindigkeitsverhalten und Verkehrssicherheit bei flachenhafter Verkehrsberuhigung]. RuhrUniversitat Bochum. 1993:335.

Brilon W, Blanke $\mathrm{H}$. Traffic safety effects from traffic calming. VTI Rapport. Vol. 363A, 1990:133-48.

London 2007 \{published data only\} Webster DC, Layfield RE. Review of $20 \mathrm{mph}$ zones in London Boroughs. TRL Published Project Report PPR243 2007.

\section{Madrid 2006 \{published data only\}}

Perez I. Safety impact of engineering treatments on undivided rural roads. Accident Analysis and Prevention 2006;38:192-200.

\section{Mørkhøj 2001 \{published data only\}}

Agustsson L. Danish experiences with speed zones/variable speed limits. Proceedings of the Conference Traffic Safety on Three Continents: International Conference in Moscow, Russia, 19-21 September, 2001 (Vti Konferens). 2001.

\section{Osaka 1998 \{published data only\}}

Yamanaka H, Yamaguchi Y, Tuchihashi M. Effect of area wide traffic calming in Japan: accident and socio-economic studies of Japanese "road-pia" projects in 1980s. Urban Transport IV: Urban Transport and the Environment for the 21st Century. 1998.

\section{Rijswijk/Eindhoven 1991 \{published data only\}}

Goos JG. Demonstration project and reconstruction of urban road networks (in the municipalities of Eindhoven and Rijswijk) [Demonstratieproject herindeling en herinricting van stedelijke gebieden (in de gemeenten Eindhoven en Rijswijk)]. SWOV 1978; R-78-15.

Janssen S. [Road safety in urban districts. Final results of accident studies in the Dutch Demonstration projects of the 1970's]. Traffic Engineering and Control 1991;32:292-6.

Janssen S. Demonstration project and reconstruction of urban road networks in the municipalities of Eindhoven and Rijswijk [Demonstratieproject herindeling en herinrichting van stedelijke gedieden (in de gemeenten Eindhoven en Rijswijk]. Institute for Road Safety Research (SWOV), The Netherlands 1984;R-84-29. Janssen S. Demonstration project and reconstruction of urban road networks in the municipalities of Eindhoven and Rijswijk [Demonstratieproject herindeling en herinrichting van stedelijke gebieden (in de gemeenten Eindhoven en Rijswijk)]. Institute for Road Safety Research Netherlands (SWOV) 1984;R-84-28-I \& R-8428-II.

Janssen S. Effects of road safety measures in urban areas in the Netherlands. Contribution to Biecheler et al (eds). "Evaluation 85", International Meeting on the Evaluation of local traffic safety measures. Institute for Road Safety Research SWOV, The Netherlands. Paris, 20-23 May 1985.

Janssen S. Evaluation of the effects of redivision measures in Eindhoven and Rijswijk [Evaluatie van de effecten van herinrichtingsmaatregelen in Eindhoven en Rijswijk]. Institute for Road Safety Research, The Netherlands (SWOV) 1980;R-80-40-I/II. * Janssen S. Final results of accident studies in the Dutch demonstration projects of the 1970's. Traffic Engineering and Control 1991;32:292-6.

Janssen S, Kraay J, Mathijssen M. The effect of traffic measures in Eindhoven and Rijswijk [De effecten van verkeersmaatregelen in Eindhoven en Rijswijk. Demonstratieproject herindeling en herinrichting van stedelijke gebieden]. Artikel Verkeerskunde 36, SWOV 1985; Vol. R-85-31.

Janssen S, Verhoef P. Demonstration project and reconstruction of urban road networks in the municipalities of Eindhoven and Rijswijk [Demonstratieproject herindeling en herinrichting van stedelijke gedieden (in de gemeenten Eindhoven en Rijswijk: Eindrapport van het ongevallen onderzoek]. Institute for Road Safety Research Netherlands (SWOV) 1989;R-89-27.

Kraay JH, Bakker MG. Experiments in residential areas [Experimenten in verblijfsruimten. Verslag van onderzoek naar de effecten van infrastructurele maatregelen op verkeersongevallen]. 
SWOV 1984;R-84-50.

Kraay JH, Remerie F. [Beleving van de verkeersonveiligheid in de herindelingsgebieden van eindhoven en rijswijk. Resultaten van een enquete in het kader van het demonstratie porject herindeling en herinrichting van stedelijke gebieden (in de gemeenten Eindhoven en Rijswijk)]. SWOV 1980;R-80-38.

Swindon 1981 \{published data only\}

Dalby E. Application of low-cost road accident countermeasures according to an area-wide strategy. Traffic Engineering \& Control 1981;22:567-74.

Sydney-Canterbury 1990 \{published data only\}

Fairlie R. Evaluation of the safety benefits of local area traffic management. M.Eng.Sc. Thesis.

Fairlie R, Taylor M. [Evaluating the safety benefits of local area traffic management]. Proceedings of the 15 th ARRB conference. 1990; Vol. 7:141-66.

Sydney-Willoughby 1990 \{published data only\}

Fairlie R. Evaluation of the safety benefits of local area traffic management. M.Eng.Sc. Thesis.

Fairlie RB, Taylor MAP. [Evaluating the safety benefits of local area traffic management]. Proceedings of the 15th ARRB conference. 1990; Vol. 7:141-66.

The Netherlands 1992 \{published data only\}

Vis AA, Dijkstra. Safety effects of $30 \mathrm{~km} / \mathrm{h}$ zones in the Netherlands. Accident Analysis and Prevention 1992;24(1):75-86.

USP Bradford 1989 \{published data only\}

Mackie AM. Urban Safety Project. 2. Interim results for area-wide schemes. Transport and Road Research Laboratory 1988;154.

* Walker R, McFetridge M. Urban safety project: The Bradford

Scheme. Transport and Road Research Laboratory, UK 1989; Vol. Contractor report 190.

\section{USP Bristol 1989 \{published data only\}}

Mackie AM. Urban safety project 2. Interim results for area wide scheme. Transport and Road Research Laboratory 1988;154.

* Ward H, Norrie J, Allsop R, Sang A. Urban Safety Project: The Bristol Scheme. Transport and Road Research Laboratory 1989;

Contractor Report 192.

USP Nelson 1989 \{published data only\}

Mackie AM. Urban safety project. 2. Interim results for area-wide schemes. Transport and Road Research Laboratory 1988;154.

* Walker R, Gardner G, McFetridge M. Urban safety project: The Nelson Scheme. Transport and Road Research Laboratory 1989; Vol. Contractor Report 191.

USP Reading 1989 \{published data only\}

Mackie AM. Urban safety project. 2. Interim results for area-wide schemes. Transport and Road Research Laboratory 1988;154.

* Ward H, Norrie J, Sang A. Urban safety scheme: The Reading Project. Transport and Road Research Laboratory 1989; Contractor Report 138.

USP Sheffield 1989 \{published data only\}

Mackie AM. Urban safety project. 2. Interim results for area-wide schemes. Transport and Road Research Laboratory 1988;154.

* Ward H, Norrie J, Sang A, Allsop R. Urban safety project: The Sheffield Scheme. Transport and Road Research Laboratory 1989; Contractor Report 134.

\section{References to studies excluded from this review}

Amundsen 1984 \{published data only\}

Amundsen FH. Speed Reducing Measures in Residential Areas.

PTRC 12th Summer Annual Meeting 1984; Proceeds of seminar L: 91-9.

Brownfield 1980 \{published data only\}

Brownfield DJ. Environmental areas - Interim report on a beforeand-after accident study. Traffic Engineering \& Control 1980;21: 279-82.

Chick 1994 \{published data only\}

Chick C. An Integrated Approach to Traffic Calming, Road Safety and Environmental Improvements in the London Borough of Hounslow. 22nd European Transport Forum, 12-16 September. Proceedings of seminar J: Traffic Management and Road Safety. 1994:53-69.

Chua 1991 \{published data only\}

Chua CS, Fisher AJ. Performance Measurements of Local Area Traffic Management: A Case Study. Australian Road Research 1991; 21(2):16-34.

Cloke 1999 \{published data only\} Cloke J, Webster D, Boulter P, Harris G, Stait R, Abbott P, et al.Traffic calming: Environmental assessment of the Leigh Park Area Safety Scheme in Havant. Vol. TRL Report 397, Transport Research Laboratory, 1999.

Cole 1990 \{published data only\} Cole A. Traffic calming trail blazers. Highways 1990;58:14-5.

Drammen Byplankontor 1980 \{published data only\} Drammen Byplankontor. [Etterproving av gjennom-kjoringsforbudet i Betzy Kjelsbergs vie]. Drammen, Drammen Kommune 1980.

Ebbecke 1977 \{published data only\} Ebbecke GM, Schuster JJ. Areawide Impact of Traffic Control Devices. Transportation Research Record 644:54-7.

Elmberg 1972 \{published data only\} Elmberg CM. The Gothenburg Traffic Restraint Scheme. Transportation 1972;5:1-27.

Engel 1982 \{published data only\} Engel U. [Short-term and area-wide evaluation of safety measures implemented in a residential area named Osterbro. A case study]. Seminar on short-term and area-wide evaluation of safety measures. 1982:251-9.

Engel 1983 \{published data only\} Engel U, Krogsgard Thomsen L. [Trafiksanering pa osterbro del 1-Ulykkesanalyse]. RfT-notat Kobenhavn, Radet for Trfiksikkerhedsforskning 1983;1.

Engel 1989a \{published data only\} Engel U, Thomsem LK. [En analyse af politirapporterede trafikulykker pa danske 40 gader baseret pa ulykkestaetheder for hhv. efter aendring af gadestatus]. Radet for Trafiksikkerhedsforskning 1989.

Engel U, Thomsen LK. Safety effects of speed reducing measures in Danish residential areas. Accident Analysis \& Prevention 1992;24(1): 17-28. 
Engel 1989b \{published data only\}

Engel U, Thomsen LK. [En analyse af politirapporterede trafikulykker pa 4440 gader og 52 kontrolgader baseret pa ulykkesfrekvenser for hhv. efter aendring af gadestatus]. Radet for Trafiksikkerheds-forskning 1989.

Engel 1990 \{published data only\}

Engel U, Thomsen LK. [En analyse af bilers korselshastigheder pa 4140 gader og 13 kontrolgader for hhv. efter aendring af gadestatus]. Radet for Trafiksikkerheds-forskning 1990.

Fager 1984 \{published data only\}

Fager M. Environmental Traffic Management in Stockholm. ITE Journal 1984:16-9.

\section{Faure 1992 \{published data only\}}

Faure A, Neuville A. Safety in urban areas: the French program

"safer city, accident-free district". Accident Analysis \& Prevention 1992;24(1):39-44.

Gambard JM, Premartin M, Wolf G. Traffic calming in France. How to live and move better in town. Revue Generale des Routes et des Aerodromes 1989:129-32.

Fisher 1989 \{published data only\}

Fisher AJ, Van Den Dool DF, Ho LK. LATM Operational Successful and Financially Affordable: But are the Users Satisfied? National Transport Conference - The Institution of Engineers, Australia 1989;89/7.

\section{Gennaoui 1987 \{published data only\}} Gennaoui FR, Smith EA. Effectiveness of LATM Devices. Fourth National Local Government Engineering Conference. 1987:6-11.

\section{Gunnarsson 1992 \{published data only\}}

Gunnarsson S, Hagson A. Traffic Management For a Swedish Historical Town [Visby Innerstad]. TFB-RAPPORT 1992:1-62.

\section{Haakenaasen 1982 \{published data only\}} Haakenaasen B. [Trafikksanering i Sandefjord sentrum. Tiltak og virkninger]. TOI-notat, Oslo Transportokonomisk 1982; Vol. 634.

Hagan 1988 \{published data only\} Hagan WB, Amamoo SE. Residential Street Management in South Australia. ITE Journal 1988:35-41.

\section{Hart 1982 \{published data only\}}

Hart M. [Effects on accidents, eliminating through traffic of cars in city areas]. Proceedings of seminar on short-term and area-wide evaluation of safety measures, Amsterdam, The Netherlands. Institute for road safety research, April 19-21 1982:127-34.

Heaton 1980 \{published data only\}

Heaton C, Goodman J. Automobile-Restrictive Measures in Central Business Districts: Some Recent Findings and Views. Transportation Research Record 1980:24-9.

HRC 1987 \{published data only\} The Highways Administration. The Town's Traffic Areas - Road Intersections. The Highways Regulations Committee, 1987.

HRC 1988 \{published data only\}

The Highways Administration. The Town's Traffic Areas - Speed Restraints. The Highways Regulations Committee, 1988.
Kraay 1984 \{published data only\}

Kraay JH, Bakker MG. [Experiments in verbliifsruimten: Verslag van onderzoek naar de effecten van infrastructurele maatregelen op verkeersongevallen]. SWOV 1984; Vol. R-84-50.

Kuemmel 1983 \{published data only\} Kuemmel DA. A Residential Traffic Management Plan in USA's Snowbelt. ITE 53rd Annual Meeting - Compendium of Technical Papers. 1983.

McDonald 1984 \{published data only\}

McDonald PE. Implementation of Local Area Traffic Management and Streetscape Improvement Scheme in Shire of Corio. ARRB Proceedings 1984;12(5):34-48.

Meyer 2000 \{published data only\}

Meyer E. Evaluation of Two Strategies for Improving Safety in Highway Work Zones. Mid-Continent Transportation Symposium 2000:62-6.

Mok 2003 \{published data only\}

Mok J, Landphair HC, Naderi JR. Comparison of safety performance of urban streets before and after landscape improvements. 2nd Urban Street Symposium, Anaheim California 2003.

Mountain 1989 \{published data only\}

Mountain L, Fawaz B. The area-wide effects of engineering measures on road accident occurrence. Traffic Engineering \& Control 1989;30:355-60.

Muskaug 1976 \{published data only\} Muskaug R. [Gatebruksplanen i Oslo. Erfaringer fra Ruselokka/ Skillebekk (forsok 1)]. Oslo Kommune, Byplankontoret, Gatebruksplangruppa 1976.

Oslo Byplankontor 1978 \{published data only\} Oslo Byplankontor. [Trafikksaneringen i Skoyen/Oppsal omradet. En vurdering av trafikksituasjonen for/etter trafikkom-legingen og de endringer som har skjedd]. Rapport 2, Oslo Kommune, Byplankontoret 1978.

Pau 2001 \{published data only\} Pau M, Angius S. Do speed bumps really decrease traffic speed? An Italian experience. Accident Analysis and Prevention 2001;33: 585-97.

Portland 2000 \{published data only\} Portland City. Portland's city-wide speed bump study: seeing the big picture. Public Works 2000;13:22-6.

Rimiller 2003 \{published data only\} Rimiller J, Ivan J, Garrick N. Estimating benefits from specific highway safety improvements: Phase III, safety benefits from left turn treatment.

Scottish Exec. 1999 \{published data only\}

Scottish Executive. Community Impact of Traffic Calming Schemes. Central Research Unit 1999; Vol. Research Findings No 68.

Scottish Executive - Development Department. Central Research Unit. Vol. Research findings no. 68, 1999.

Stolen 1988 \{published data only\} Stolan A. [Erfaringer med trafikksaneringer og sammenhengende gang-og sykkelveger. Oslo, Asplan Samferdsel]. Utgitt av Samferdselsdepartementet og Vegdirektoratet 1988. 
Tester 2004 \{published data only\}

Tester JM, Rutherford GW, Wald Z, Rutherford MW. A matched case-control study evaluating the effectiveness of speed humps in reducing child pedestrian injuries. American Journal of Public Health 2004;94(4):646-50.

TRL 1997 \{published data only\}

Transport Research Laboratory. Core Calming. Highways 1997: 28-9.

\section{Vreugdenhil 1972 \{published data only\}}

Vreugdenhil JJ. Residential Street Design with Special Emphasis on the Reduction of Accidents and the Improvement of the Environment. ARRB Proceedings 1972;6:3-52.

Vreugdenhil 1976 \{published data only\}

Vreugdenhil JJ. Traffic Managment Schemes For Existing Residential Street Layouts on the Grid System. ARRB Proceedings 1976;8:1-50.

\section{References to studies awaiting assessment}

\section{Grontmij 1991 \{published data only\}}

Grontmij. Evaluation of experimental thirty kilometer-zones: a study into traffic accidents [Evaluatie experiments $30 \mathrm{KM} / \mathrm{H}$

Zones: Verkeersongevallenonderzoek].

\section{References to ongoing studies}

\section{Towliat \{published data only\}}

Towliat M. Experiments regarding safety measures for pedestrian and cyclist in interactions with cars on main roads in built up areas. Lund University.

\section{Additional references}

\section{Barss 1998}

Barss P. Injury prevention: an international perspective epidemiology, surveillance and policy. OUP, 1998.

\section{Elvik 2001}

Elvik R. Area-wide urban traffic calming schemes: a meta-analysis of safety effects. Accident Analysis \& Prevention 2001;33:327-36.

Krug 2002

Krug E (Ed). Injury a leading cause of the Global burden of disease. Geneva: World Health Organization, 2002.

\section{Murray 1997}

Murray CJL, Lopez AD. Alternative projections of mortality and disability by cause 1990-2020: Global Burden of Disease Study. Lancet 1997;349:1498-504.

\section{Review Manager}

The Nordic Cochrane Centre. Review Manager. 5.0. Copenhagen: The Cochrane Collaboration, 2008.

\section{Roberts 1995}

Roberts, I. Letter from Chengdu: China takes to the roads. BMJ 1995;311:1311-3.

\section{Wentz 2001}

Wentz R, Roberts I, Bunn F, Edwards P, Kwan I, Lefebvre C. Identifying controlled evaluation studies of road safety interventions searching for needles in a haystack. Journal of Safety Research 2001;32:267-76.

\section{WHO 2009}

WHO. Global status report on road safety: time for action. World Health Organization, Geneva. (www.who.int/ violence injury' prevention/road'safety'status/2009) 2009.

* Indicates the major publication for the study 


\section{CHARACTERISTICS OF STUDIES}

\section{Characteristics of included studies [ordered by study ID]}

\section{Charlottenburg 1990}

\begin{tabular}{ll}
\hline Methods & $\begin{array}{l}\text { CBA } \\
2 \text { yrs before data. } \\
2 \text { yrs after data. }\end{array}$ \\
\hline Participants & $\begin{array}{l}\text { I) Densely populated residential area with small businesses. } \\
\text { C) Berlin-Moabit }\end{array}$ \\
\hline Interventions & $\begin{array}{l}\text { I) Various traffic calming measures including different levels of road surface, staggered lanes and 30km speed limit. } \\
\text { C) No traffic calming. }\end{array}$ \\
\hline Outcomes & $\begin{array}{l}\text { Road traffic crash related deaths and injuries. } \\
\text { All road traffic crashes. }\end{array}$ \\
\hline Notes & This was a pilot study for the German study on traffic calming in six towns. \\
\hline
\end{tabular}

\section{Column totals}

\begin{tabular}{l|l}
\hline Methods & $\begin{array}{l}\text { This does not refer to a separate study. } \\
\text { The 'column totals identifier is used for the pooled analysis of road user deaths and pedestrian-motor vehicle collisions, } \\
\text { due to the presence of zero events in } \geq 1 \text { of the study periods. }\end{array}$ \\
\hline Participants & \\
\hline Interventions & \\
\hline Outcomes & \\
\hline Notes
\end{tabular}

\section{Denmark 1992}

\begin{tabular}{|c|c|}
\hline Methods & $\begin{array}{l}\text { CBA } \\
3 \text { yrs before data. } \\
3 \text { yrs after data. }\end{array}$ \\
\hline Participants & $\begin{array}{l}\text { I) } 515 \mathrm{~km} / \mathrm{h} \text { streets and } 3930 \mathrm{~km} / \mathrm{h} \text { streets comprising } 30 \mathrm{~km} \text { of road } \\
\text { C) } 52 \text { control streets comprising } 35 \mathrm{~km} \text { of road }\end{array}$ \\
\hline Interventions & $\begin{array}{l}\text { I) Area-wide traffic calming including speed humps, limited road width, lateral dislocation } \\
\text { C) No area-wide traffic calming }\end{array}$ \\
\hline Outcomes & Road traffic crash related injuries, deaths, and serious injuries \\
\hline
\end{tabular}


Denmark 1992 (Continued)

Notes Collision data collected from police records

\section{GST-Borgentreich 1993}

\begin{tabular}{ll}
\hline Methods & $\begin{array}{l}\text { CBA } \\
3 \text { yrs before data. } \\
3 \text { yrs after data. }\end{array}$ \\
\hline Participants & $\begin{array}{l}\text { I) Entire centre of Borgentreich. It is a mixture of residential, commercial and farm properties. } \\
\text { C) Borgholz }\end{array}$ \\
\hline Interventions & $\begin{array}{l}\text { I) Area-wide traffic calming including road narrowing, redesign of major roads, traffic free zones, speed restrictions. } \\
\text { C) No area-wide traffic calming. }\end{array}$ \\
\hline Outcomes & $\begin{array}{l}\text { Road traffic crash related deaths and injuries. } \\
\text { All road traffic crashes. } \\
\text { Pedestrian crashes. }\end{array}$ \\
\hline Notes & $\begin{array}{l}\text { Part of the German study on traffic calming in six towns. } \\
\text { Injury data collected from police records. } \\
\text { No information given on perceived safety or quality of environment. }\end{array}$ \\
\hline
\end{tabular}

\section{GST-Buxtehude 1993}

\begin{tabular}{|c|c|}
\hline Methods & $\begin{array}{l}\text { CBA } \\
2 \text { yrs before data. } \\
2 \text { yrs after data. }\end{array}$ \\
\hline Participants & $\begin{array}{l}\text { I) The northern half of the centre of Buxtehude, a mix of shopping and residential areas. } \\
\text { C) Areas to the south in Buxtehude. }\end{array}$ \\
\hline Interventions & $\begin{array}{l}\text { I) Measures included road narrowing, speed restrictions and a wide range of traffic restraint measures. } \\
\text { C) No area-wide traffic calming. }\end{array}$ \\
\hline Outcomes & $\begin{array}{l}\text { Road traffic crash related deaths and injuries. } \\
\text { All road traffic crashes. } \\
\text { Pedestrian crashes. }\end{array}$ \\
\hline Notes & $\begin{array}{l}\text { Part of the German study on traffic calming in six towns. } \\
\text { Injury data collected from police records. } \\
\text { No information given on perceived safety or quality of environment. }\end{array}$ \\
\hline
\end{tabular}


GST-Esslingen 1993

\begin{tabular}{ll}
\hline Methods & $\begin{array}{l}\text { CBA } \\
2 \text { yrs before data. } \\
2 \text { yrs after data. }\end{array}$ \\
\hline Participants & $\begin{array}{l}\text { I) Area of the town which is a mixture of residential, industrial and commercial properties. } \\
\text { C) Similar district in Nurtingen. }\end{array}$ \\
\hline Interventions & $\begin{array}{l}\text { I) Area-wide traffic calming including reconstruction of major roads and renewal of residential roads. } \\
\text { C) No area-wide traffic calming. }\end{array}$ \\
\hline Outcomes & $\begin{array}{l}\text { Road traffic crash related deaths and injuries. } \\
\text { All road traffic crashes. } \\
\text { Pedestrian crashes. }\end{array}$ \\
\hline Notes & $\begin{array}{l}\text { Part of the German study on traffic calming in six towns. } \\
\text { Injury data collected from police records. } \\
\text { No information given on perceived safety or quality of environment. }\end{array}$ \\
\hline
\end{tabular}

\section{GST-Ingolstadt 1993}

\begin{tabular}{ll}
\hline Methods & $\begin{array}{l}\text { CBA } \\
2 \text { yrs before data. } \\
2 \text { yrs after data. }\end{array}$ \\
\hline Participants & $\begin{array}{l}\text { I) Most of the old part of the town. } \\
\text { C) Old part of the town of Regensburg. }\end{array}$ \\
\hline Interventions & $\begin{array}{l}\text { I) Area-wide traffic calming including street renewal. } \\
\text { C) No area-wide traffic calming. }\end{array}$ \\
\hline Outcomes & $\begin{array}{l}\text { Road traffic crash related deaths and injuries. } \\
\text { All road traffic crashes. } \\
\text { Pedestrian crashes. }\end{array}$ \\
\hline Notes & $\begin{array}{l}\text { Part of the German study on traffic calming in six towns. } \\
\text { Injury data collected from police records. } \\
\text { No information given on perceived safety or quality of environment. }\end{array}$ \\
\hline
\end{tabular}

\section{GST-Mainz 1993}

\begin{tabular}{ll} 
Methods & $\begin{array}{l}\text { CBA } \\
2 \text { yrs before data. } \\
2 \text { yrs after data. }\end{array}$ \\
\hline Participants & $\begin{array}{l}\text { I) Rural area of Mainz (Mainz-Bretzenheim). Area was } 200 \text { hectares with 11,000 inhabitants. } \\
\text { C) Another part of Mainz (Mainz-Finthen). }\end{array}$
\end{tabular}


GST-Mainz 1993 (Continued)

\begin{tabular}{ll}
\hline Interventions & $\begin{array}{l}\text { I) Area-wide traffic calming including reconstruction of public spaces, road narrowing and narrowing of road en- } \\
\text { trances. } \\
\text { C) No area-wide traffic calming. }\end{array}$ \\
\hline Outcomes & $\begin{array}{l}\text { Road traffic crash related deaths and injuries. } \\
\text { All road traffic crashes. } \\
\text { Pedestrian crashes. }\end{array}$ \\
\hline Notes & $\begin{array}{l}\text { Part of the German study on traffic calming in six towns. } \\
\text { Injury data collected from police records. } \\
\text { No information given on perceived safety or quality of environment. }\end{array}$ \\
\hline
\end{tabular}

\section{GST-Moabit 1993}

\begin{tabular}{ll}
\hline Methods & CBA \\
& $\begin{array}{l}\text { 2 yrs before data. } \\
2 \text { yrs after data. }\end{array}$ \\
\hline Participants & $\begin{array}{l}\text { I) Densely populated residential area near the city centre. } \\
\text { C) A part of the district Berlin-Wedding. }\end{array}$ \\
\hline Interventions & $\begin{array}{l}\text { I) Area-wide traffic calming including rebuilding of major roads and increasing the level of vegetation in streets. } \\
\text { C) No area-wide traffic calming. }\end{array}$ \\
\hline Outcomes & $\begin{array}{l}\text { Road traffic crash related deaths and injuries. } \\
\text { All road traffic crashes. } \\
\text { Pedestrian crashes. }\end{array}$ \\
\hline Notes & $\begin{array}{l}\text { Part of the German study on traffic calming in six towns. } \\
\text { No information given on perceived safety or quality of environment. }\end{array}$ \\
\hline
\end{tabular}

London 2007

\begin{tabular}{ll}
\hline Methods & CBA \\
& I) 5 yrs before data \\
$1-5$ yrs after data \\
C) 5 yrs before data \\
3 yrs after data
\end{tabular}


London 2007 (Continued)

\begin{tabular}{l|l} 
Outcomes & $\begin{array}{l}\text { Road traffic crash related injuries, deaths and serious injuries, and injuries to pedestrians, cyclists, powered 2-wheeler } \\
\text { riders, and car occupants. } \\
\text { All road traffic crashes and crashes involving a death or serious injury. } \\
\text { Road traffic crash related injuries to children. }\end{array}$ \\
\hline Notes & Collision data collected from police records. \\
\hline
\end{tabular}

\section{Madrid 2006}

\begin{tabular}{ll} 
Methods & $\begin{array}{l}\text { CBA } \\
2 \text { yrs before data } \\
2 \text { yrs after data }\end{array}$ \\
\hline Participants & $\begin{array}{l}\text { I) Undivided rural roads belonging to the highway network of the Autonomous Community of Madrid that received } \\
\text { treatment between } 1986 \text { and } 1989 . \\
\text { C) Undivided rural roads belonging to the highway network of the Autonomous Community of Madrid that received } \\
\text { treatment between } 1990 \text { and 1993. i.e. roads that during the time period of the study did not receive treatment but } \\
\text { would later be treated. }\end{array}$ \\
\hline Interventions & $\begin{array}{l}\text { I) Highway upgrading, traffic signing, pavement markings, pavement resurfacing } \\
\text { C) No area-wide traffic calming }\end{array}$ \\
\hline Outcomes & Number of road traffic crashes \\
\hline Notes & Data could not be extracted
\end{tabular}

\section{Mørkhøj 2001}

\begin{tabular}{ll} 
Methods & $\begin{array}{l}\text { CBA } \\
3 \text { yrs before data } \\
3 \text { yrs after data }\end{array}$ \\
\hline Participants & $\begin{array}{l}\text { I) Residential area with both single-family houses and flats totaling } 15.5 \mathrm{~km} \\
\text { C) The remainder of the Gladsaxe Municipality }\end{array}$ \\
\hline Interventions & $\begin{array}{l}\text { I) Speed humps, raised crossings, road signs and increased vegetation } \\
\text { C) No area-wide traffic calming }\end{array}$ \\
\hline Outcomes & Road traffic crashes \\
\hline Notes & $\begin{array}{l}\text { The intervention area had been suffering from a high accident rate before the intervention. Speed reducing measures } \\
\text { in the intervention area were placed further apart than recommended in Danish road guidelines. }\end{array}$ \\
\hline
\end{tabular}


Osaka 1998

\begin{tabular}{ll}
\hline Methods & $\begin{array}{l}\text { CBA } \\
6 \text { yrs before data } \\
6 \text { yrs after data }\end{array}$ \\
\hline Participants & $\begin{array}{l}\text { Ia) } 10 \text { districts in Osaka with "road-pia" projects that started in } 1987 \text { or earlier } \\
\text { Ib) } 9 \text { districts in Osaka with "community street" projects } \\
\text { C) } 9 \text { districts in Osaka }\end{array}$ \\
\hline Interventions & $\begin{array}{l}\text { Ia) "Road-pia" project introduced area-wide traffic calming including speed humps, limited street width, coloured } \\
\text { pavement, chicanes, and entry treatments. } \\
\text { Ib) "Community street" projects introduces chicanes, improved pavements, street furniture, and increased vegetation. } \\
\text { C) No area-wide traffic calming }\end{array}$ \\
\hline Outcomes & $\begin{array}{l}\text { Road traffic crashes } \\
\text { Pedestrian crashes } \\
\text { Cyclist crashes }\end{array}$ \\
\hline Notes & Collision data collected from police records. \\
\hline
\end{tabular}

\section{Rijswijk/Eindhoven 1991}

\begin{tabular}{ll}
\hline Methods & $\begin{array}{l}\text { CBA } \\
6 \text { yrs before data. } \\
5 \text { yrs after data. }\end{array}$ \\
\hline Participants & $\begin{array}{l}\text { I) Road districts in Rijswijk and Eindhoven in the Netherlands. The project began in } 1976 . \\
\text { C) Number of residential zones bordering on main traffic arteries within the boundaries of Rijswijk and Eindhoven. } \\
\text { They were not in the immediate vicinity of the intervention areas. } \\
\text { The experimental areas in Rijswijk consisted mainly of old residential districts whereas the control area is made up } \\
\text { of new housing estates. } \\
\text { Each area was about } 100 \text { hectares. }\end{array}$ \\
\hline Interventions & $\begin{array}{l}\text { I) Public spaces were first reclassified, with a new distribution of traffic zones and zones for other functions. The } \\
\text { traffic zones were then reconstructed in order to improve road safety and traffic flow. Interventions included: road } \\
\text { humps, horizontal road shifts, road closures and restrictions, road narrowing and raised cross-roads. } \\
\text { C) No traffic calming. }\end{array}$ \\
\hline Outcomes & $\begin{array}{l}\text { Road traffic crash related deaths and injuries. } \\
\text { Environmental effect. } \\
\text { Retail sales. } \\
\text { Public opinion. }\end{array}$ \\
\hline Notes & $\begin{array}{l}\text { Project began in 1976. The control areas were larger than the intervention areas and had many more residents. } \\
\text { However, the residential density per hector was higher in the intervention area. }\end{array}$ \\
\hline
\end{tabular}


Swindon 1981

\begin{tabular}{|c|c|}
\hline Methods & $\begin{array}{l}\text { CBA } \\
4 \text { yrs before data. } \\
2 \text { yrs after data. }\end{array}$ \\
\hline Participants & $\begin{array}{l}\text { I) } 2.8 \mathrm{KM} \text { section of an all purpose arterial road in Swindon, UK } \\
\text { C) Three routes of similar layout, frontage development and radial function. The local council agreed to keep road } \\
\text { works to a minimum in this area. }\end{array}$ \\
\hline Interventions & $\begin{array}{l}\text { I) A number of traffic calming measures including roundabouts, pedestrian crossings and changes to intersections. } \\
\text { C) No changes. }\end{array}$ \\
\hline Outcomes & Road traffic crash related injuries. \\
\hline Notes & $\begin{array}{l}\text { Behaviour of the control routes was atypical of other types of road in Swindon during the study period. } \\
\text { No information given on perceived safety or quality of environment. }\end{array}$ \\
\hline
\end{tabular}

\section{Sydney-Canterbury 1990}

\begin{tabular}{ll}
\hline Methods & CBA \\
& $\begin{array}{l}3 \text { yrs before data. } \\
2.5 \text { yrs after data. } \\
\text { The control area was chosen due to its closeness to the trial area and its similar characteristics. }\end{array}$ \\
\hline Participants & $\begin{array}{l}\text { I) Predominantly residential area in Sydney, Australia. The area also contained an industrial zone. } \\
\text { C) An area to the south of the test area. This area was different in that it did not contain an industrial zone. }\end{array}$ \\
\hline Interventions & $\begin{array}{l}\text { I) Local area traffic management scheme (LATM) implemented in 1982, including speed humps, slow points, } \\
\text { roundabouts and a 40km speed limit. } \\
\text { C) No LATM scheme. }\end{array}$ \\
\hline Outcomes & $\begin{array}{l}\text { Road traffic crash related deaths and injuries. } \\
\text { All road traffic crashes. } \\
\text { Pedestrian crashes. } \\
\text { Residents opinions on the value of LATM. }\end{array}$ \\
\hline Notes & $\begin{array}{l}\text { The schemes in Canterbury and Willoughby are both reported in the same paper. } \\
\text { Collision data collected from police records. }\end{array}$ \\
\hline
\end{tabular}

\section{Sydney-Willoughby 1990}

\begin{tabular}{ll}
\hline Methods & $\begin{array}{l}\text { CBA } \\
2 \text { yrs before data. } \\
2 \text { yrs after data. }\end{array}$ \\
\hline Participants & $\begin{array}{l}\text { I) Predominantly residential area in Sydney, Australia. } \\
\text { C) Selected because of its similar traffic problems to the interventions area. The street network of the control area, } \\
\text { however, did not reflect the grid pattern of the study area. }\end{array}$
\end{tabular}




\section{Sydney-Willoughby 1990 (Continued)}

\begin{tabular}{ll} 
Interventions & $\begin{array}{l}\text { I) A LATM scheme with dense coverage of devices including entry thresholds, slow points, speed humps, T-inter- } \\
\text { section treatments, roundabouts and road closures. } \\
\text { C) No LATM. }\end{array}$ \\
\hline Outcomes & $\begin{array}{l}\text { Road traffic crash related deaths and injuries. } \\
\text { All road traffic crashes. } \\
\text { Pedestrian crashes. } \\
\text { Residents opinions on the value of LATM. }\end{array}$ \\
\hline Notes & The schemes in Canterbury and Willoughby are both reported in the same paper. \\
\hline
\end{tabular}

\section{The Netherlands 1992}

\begin{tabular}{ll} 
Methods & CBA \\
\hline Participants & $\begin{array}{l}\text { I) } 15 \text { areas throughout the Netherlands } \\
\text { C) Built-up areas (excluding arterial roads) of the municipalities where the interventions were situated }\end{array}$ \\
\hline Interventions & $\begin{array}{l}\text { I) } 30 \mathrm{~km} / \mathrm{h} \text { zones including signs, road humps, limited road width, elongated humps, raised sections, traffic islands } \\
\text { and refuges, mini roundabouts, turning bans, diagonal closures, and speed humps with special cycle lanes. } \\
\text { C) No area-wide traffic calming }\end{array}$ \\
\hline Outcomes & $\begin{array}{l}\text { Traffic speeds } \\
\text { Traffic volumes } \\
\text { Road traffic crashes }\end{array}$ \\
\hline Notes & Could not extract data \\
\hline
\end{tabular}

\section{USP Bradford 1989}

\begin{tabular}{ll}
\hline Methods & $\begin{array}{l}\text { CBA } \\
5 \text { yrs before data. } 2 \text { yrs after data. }\end{array}$ \\
\hline Participants & $\begin{array}{l}\text { I) Area in Bradford to the South west of the city centre, with a population of 33,000 in around 12,000 households. } \\
\text { The area was mainly residential in generally unplanned street system. } \\
\text { C) Area of much the same size and character on the opposite side of the city. }\end{array}$ \\
\hline Interventions & $\begin{array}{l}\text { I) General area wide scheme including: junction redesign, closures of through routes; and installation of central } \\
\text { refuges. } \\
\text { C) No area-wide traffic calming. }\end{array}$ \\
\hline Outcomes & $\begin{array}{l}\text { Road traffic crash related deaths and injuries. } \\
\text { Pedestrian crashes. }\end{array}$ \\
\hline Notes & $\begin{array}{l}\text { One of the five cities and towns involved in the Urban Safety Project led by the Transport and Road Research } \\
\text { Laboratory, UK. } \\
\text { Injury data collected from police records. }\end{array}$
\end{tabular}


USP Bradford 1989 (Continued)

No information given on perceived safety or quality of environment.

\section{USP Bristol 1989}

\begin{tabular}{ll}
\hline Methods & $\begin{array}{l}\text { CBA } \\
5 \text { yrs before data. } 2 \text { yrs after data. }\end{array}$ \\
\hline Participants & $\begin{array}{l}\text { I) An area covering approximately } 10 \text { square km north of central Bristol. In } 1981 \text { the population was approximately } \\
32,000 \text { in about } 12,000 \text { households. } \\
\text { The area is predominantly residential with roughly equal amounts of local authority housing and private housing. } \\
\text { C) An area of similar size and character to the south of the city centre. }\end{array}$ \\
\hline Interventions & $\begin{array}{l}\text { I) General area wide scheme including: Junction redesign, Mini-roundabout, Right turn bans, Improvement of } \\
\text { pedestrian crossings, Improved road signs and markings, Road closures. } \\
\text { C) No area-wide traffic calming. }\end{array}$ \\
\hline Outcomes & $\begin{array}{l}\text { Road traffic crash related deaths and injuries. } \\
\text { Pedestrian crashes. }\end{array}$ \\
\hline Notes & $\begin{array}{l}\text { One of the five cities and towns involved in the Urban safety project led by the Transport and Road Research } \\
\text { Laboratory, UK. } \\
\text { Injury data collected from police records. } \\
\text { No information given on perceived safety or quality of environment. }\end{array}$ \\
\hline
\end{tabular}

\section{USP Nelson 1989}

\begin{tabular}{|c|c|}
\hline Methods & $\begin{array}{l}\text { CBA } \\
5 \text { yrs before data. } \\
2 \text { yrs after data. }\end{array}$ \\
\hline Participants & $\begin{array}{l}\text { I) An area that consists mainly of the town of Nelson (excluding the town centre), covering an area of } 7 \text { square } \mathrm{km} \text {. } \\
\text { In } 1981 \text { it had approximately } 11,400 \text { households with } 30,000 \text { people. Many pre-1914 houses in long terraces, some } \\
\text { post- } 1945 \text { local authority housing. Steep hills. } \\
\text { C) An area of approximately the same size and character in the adjacent district of Burnley. The centre of Burnley } \\
\text { lies about } 3 \text { miles to the south of Nelson. }\end{array}$ \\
\hline Interventions & I) General area wide scheme including: Junction redesign, Road closures, Mini-roundabouts. \\
\hline Outcomes & $\begin{array}{l}\text { Road traffic crash related deaths and injuries. } \\
\text { Pedestrian crashes. }\end{array}$ \\
\hline Notes & $\begin{array}{l}\text { One of the five cities and towns involved in the Urban safety project led by the Transport and Road Research } \\
\text { Laboratory, UK. } \\
\text { No information given on perceived safety or quality of environment. }\end{array}$ \\
\hline
\end{tabular}


USP Reading 1989

\begin{tabular}{ll}
\hline Methods & $\begin{array}{l}\text { CBA } \\
5 \text { yrs before data. Nearly } 2 \text { yrs after data. } \\
\text { A comparable control area in the same city was chosen. }\end{array}$ \\
\hline Participants & $\begin{array}{l}\text { I) An area to the west of the central commercial area which covers approximately } 8 \text { square km. } \\
\text { In } 1981 \text { area had a population of about } 36,000 \text { people occupying } 15,000 \text { households. } \\
\text { C) An area similar in size to the southeast of the central area. }\end{array}$ \\
\hline Interventions & $\begin{array}{l}\text { I) General area wide scheme including: } \\
\text { Road closures, Right turn bans, Mini roundabouts. }\end{array}$ \\
\hline Outcomes & $\begin{array}{l}\text { Road traffic crash related deaths and injuries. } \\
\text { Pedestrian crashes. }\end{array}$ \\
\hline Notes & $\begin{array}{l}\text { One of the five cities and towns involved in the Urban safety project led by the Transport and Road Research } \\
\text { Laboratory, UK. } \\
\text { Injury data collected from police records. } \\
\text { Modifications to the design of the measures was made in the first } 9 \text { months in response to localised increases in the } \\
\text { number of accidents. } \\
\text { No information given on perceived safety or quality of environment. }\end{array}$ \\
\hline
\end{tabular}

\section{USP Sheffield 1989}

\begin{tabular}{ll} 
Methods & $\begin{array}{l}\text { CBA } \\
5 \text { yrs before data. } 2 \text { yrs after data. }\end{array}$ \\
\hline Participants & $\begin{array}{l}\text { I) An area to the north of the city centre covering approximately } 9 \text { square km. } \\
\text { In } 1981 \text { the population of the area was approximately } 50,000 \text { people in about } 18,000 \text { houses. } \\
\text { The area is mostly residential and consisting largely of local authority housing. } \\
\text { C) An area of similar size and character to the south of the city centre. }\end{array}$ \\
\hline Interventions & $\begin{array}{l}\text { I) General area wide scheme including: } \\
\text { Road closures, traffic islands, central refuges, additional pedestrian crossings, and turning restrictions. } \\
\text { C) No traffic calming measures. }\end{array}$ \\
\hline Outcomes & $\begin{array}{l}\text { Road traffic crash related deaths and injuries. } \\
\text { Pedestrian crashes. }\end{array}$ \\
\hline Notes & $\begin{array}{l}\text { One of the five cities and towns involved in the Urban safety project led by the Transport and Road Research } \\
\text { Laboratory, UK. } \\
\text { Injury data collected from police records. } \\
\text { No information given on perceived safety or quality of environment. }\end{array}$ \\
\hline
\end{tabular}

$\mathrm{CBA}=$ Controlled-before-after study

$\mathrm{I}=$ Intervention

$\mathrm{C}=$ Control

LATM = local area traffic management scheme 
Characteristics of excluded studies [ordered by study ID]

\begin{tabular}{|c|c|}
\hline Amundsen 1984 & Uncontrolled before/after \\
\hline Brownfield 1980 & Uncontrolled before/after \\
\hline Chick 1994 & Uncontrolled before/after \\
\hline Chua 1991 & Uncontrolled before/after \\
\hline Cloke 1999 & Uncontrolled before/after \\
\hline Cole 1990 & Uncontrolled before/after \\
\hline Drammen Byplankontor 1980 & Uncontrolled before/after \\
\hline Ebbecke 1977 & Uncontrolled before/after \\
\hline Elmberg 1972 & Uncontrolled before/after \\
\hline Engel 1982 & Not area-wide traffic calming \\
\hline Engel 1983 & Uncontrolled before/after \\
\hline Engel 1989a & Not area-wide traffic calming \\
\hline Engel 1989b & Not area-wide traffic calming \\
\hline Engel 1990 & Not area-wide traffic calming \\
\hline Fager 1984 & Uncontrolled before/after \\
\hline Faure 1992 & Uncontrolled before/after \\
\hline Fisher 1989 & Uncontrolled before/after \\
\hline Gennaoui 1987 & Uncontrolled before/after \\
\hline Gunnarsson 1992 & Uncontrolled before/after \\
\hline Haakenaasen 1982 & Uncontrolled before/after \\
\hline Hagan 1988 & Uncontrolled before/after \\
\hline Hart 1982 & Uncontrolled before/after \\
\hline Heaton 1980 & Uncontrolled before/after \\
\hline
\end{tabular}


(Continued)

\begin{tabular}{|c|c|}
\hline HRC 1987 & Uncontrolled before/after \\
\hline HRC 1988 & Uncontrolled before/after \\
\hline Kraay 1984 & Unable to locate full text to enable assessment for inclusion. \\
\hline Kuemmel 1983 & Uncontrolled before/after \\
\hline McDonald 1984 & Uncontrolled before/after \\
\hline Meyer 2000 & Uncontrolled before/after \\
\hline Mok 2003 & Uncontrolled before/after \\
\hline Mountain 1989 & Uncontrolled before/after \\
\hline Muskaug 1976 & Uncontrolled before/after \\
\hline Oslo Byplankontor 1978 & Uncontrolled before/after \\
\hline Pau 2001 & Uncontrolled before/after \\
\hline Portland 2000 & Uncontrolled before/after \\
\hline Rimiller 2003 & Only evaluated "road diet" interventions \\
\hline Scottish Exec. 1999 & Uncontrolled before/after \\
\hline Stolen 1988 & Uncontrolled before/after \\
\hline Tester 2004 & Case-control \\
\hline TRL 1997 & Uncontrolled before/after \\
\hline Vreugdenhil 1972 & Uncontrolled before/after \\
\hline Vreugdenhil 1976 & Uncontrolled before/after \\
\hline
\end{tabular}

\section{Characteristics of ongoing studies [ordered by study ID]}

\section{Towliat}

\begin{tabular}{ll}
\hline Trial name or title & Stockholm \\
\hline Methods & CBA
\end{tabular}




\section{Towliat (Continued)}

\section{$\begin{array}{ll}\text { Participants } & \text { I) } 20 \text { areas in Stockholm and Örebro }\end{array}$}

C) 18 areas in Stockholm and Örebro

\begin{tabular}{ll}
\hline Interventions & I) Road cushions, road narrowing, handrails and lampposts at pedestrian and cyclist crossings \\
\hline Outcomes & $\begin{array}{l}\text { traffic speeds } \\
\text { motorists-pedestrian/cyclist conflicts } \\
\text { motorist behaviour } \\
\text { road user opinions }\end{array}$ \\
\hline Starting date & 1997 \\
\hline Contact information & Lund University, Department of Technology and Society \\
\hline Notes &
\end{tabular}


DATA AND ANALYSES

Comparison 1. Area-wide traffic calming versus control

\begin{tabular}{|c|c|c|c|c|}
\hline Outcome or subgroup title & $\begin{array}{l}\text { No. of } \\
\text { studies }\end{array}$ & $\begin{array}{c}\text { No. of } \\
\text { participants }\end{array}$ & Statistical method & Effect size \\
\hline 1 Road user deaths & 1 & & Rate Ratio (Random, 95\% CI) & $0.79[0.23,2.68]$ \\
\hline 2 Road user injuries & 18 & & Rate Ratio (Random, 95\% CI) & $0.85[0.75,0.96]$ \\
\hline 3 Road traffic crashes & 12 & & Rate Ratio (Random, 95\% CI) & $0.89[0.76,1.05]$ \\
\hline $\begin{array}{l}4 \text { Pedestrian-motor vehicle } \\
\text { collisions }\end{array}$ & 1 & & Rate Ratio (Random, 95\% CI) & $1.01[0.88,1.16]$ \\
\hline
\end{tabular}

Analysis I.I. Comparison I Area-wide traffic calming versus control, Outcome I Road user deaths.

Review: Area-wide traffic calming for preventing traffic related injuries

Comparison: I Area-wide traffic calming versus control

Outcome: I Road user deaths




Analysis I.2. Comparison I Area-wide traffic calming versus control, Outcome 2 Road user injuries.

Review: Area-wide traffic calming for preventing traffic related injuries

Comparison: I Area-wide traffic calming versus control

Outcome: 2 Road user injuries

Study or subgroup $\quad \log$ [Rate Ratio] Rate Ratio Weight Ratio Ratio

Charlottenburg 1990

$-0.7449(0.3844)$

IV,Random,95\% Cl

IV,Random,95\% C

Denmark 1992

$-1.0127(0.4619)$

GST-Borgentreich 1993

$-0.1252(0.7586)$

GST-Buxtehude 1993

$0.4782(0.276)$

GST-Esslingen 1993

$-0.0308(0.2098)$

GST-Ingolstadt 1993

$0.1159(0.1475)$

GST-Mainz 1993

$0.011(0.4039)$

GST-Moabit 1993

$-0.2212(0.1149)$

London 2007

$-0.5198(0.0876)$

Rijswijk/Eindhoven 1991

$-0.3285(0.0618)$

Swindon 1981

$-0.3537(0.1963)$

Sydney-Canterbury 1990

$-0.1787(0.213)$

Sydney-Willoughby 1990

$-0.0187(0.3614)$

USP Bradford 1989

$-0.0673(0.1139)$

USP Bristol 1989

$0.0459(0.1103)$

USP Nelson 1989

$-0.0741(0.1156)$

USP Reading 1989

$0.0754(0.1006)$

USP Sheffield 1989

$-0.366(0.117)$

$2.2 \%$

$0.47[0.22,1.01]$

$0.36[0.15,0.90]$

$0.7 \%$

$0.88[0.20,3.90]$

$3.5 \%$

$1.61[0.94,2.77]$

$4.9 \%$

$0.97[0.64,1.46]$

$6.7 \%$

$1.12[0.84,1.50]$

$2.0 \%$

$1.01[0.46,2.23]$

$7.8 \%$

$0.80[0.64,1.00]$

$8.8 \%$

$0.59[0.50,0.71]$

$9.5 \%$

$0.72[0.64,0.81]$

$5.3 \%$

$0.70[0.48,1.03]$

$4.8 \%$

$0.84[0.55,1.27]$

$2.4 \%$

$0.98[0.48,1.99]$

$7.9 \%$

$0.93[0.75,1.17]$

$8.0 \%$

$1.05[0.84,1.30]$

$7.8 \%$

$0.93[0.74,1.16]$

$8.3 \%$

$1.08[0.89,1.31]$

$7.8 \%$

$0.69[0.55,0.87$ ]

\section{Total (95\% CI)}

Heterogeneity: $\operatorname{Tau}^{2}=0.04 ; \mathrm{Chi}^{2}=52.24, \mathrm{df}=17(\mathrm{P}=0.00002) ; \mathrm{I}^{2}=67 \%$

Test for overall effect: $Z=2.53(P=0.011)$

$100.0 \%$ 
Analysis I.3. Comparison I Area-wide traffic calming versus control, Outcome 3 Road traffic crashes.

Review: Area-wide traffic calming for preventing traffic related injuries

Comparison: I Area-wide traffic calming versus control

Outcome: 3 Road traffic crashes

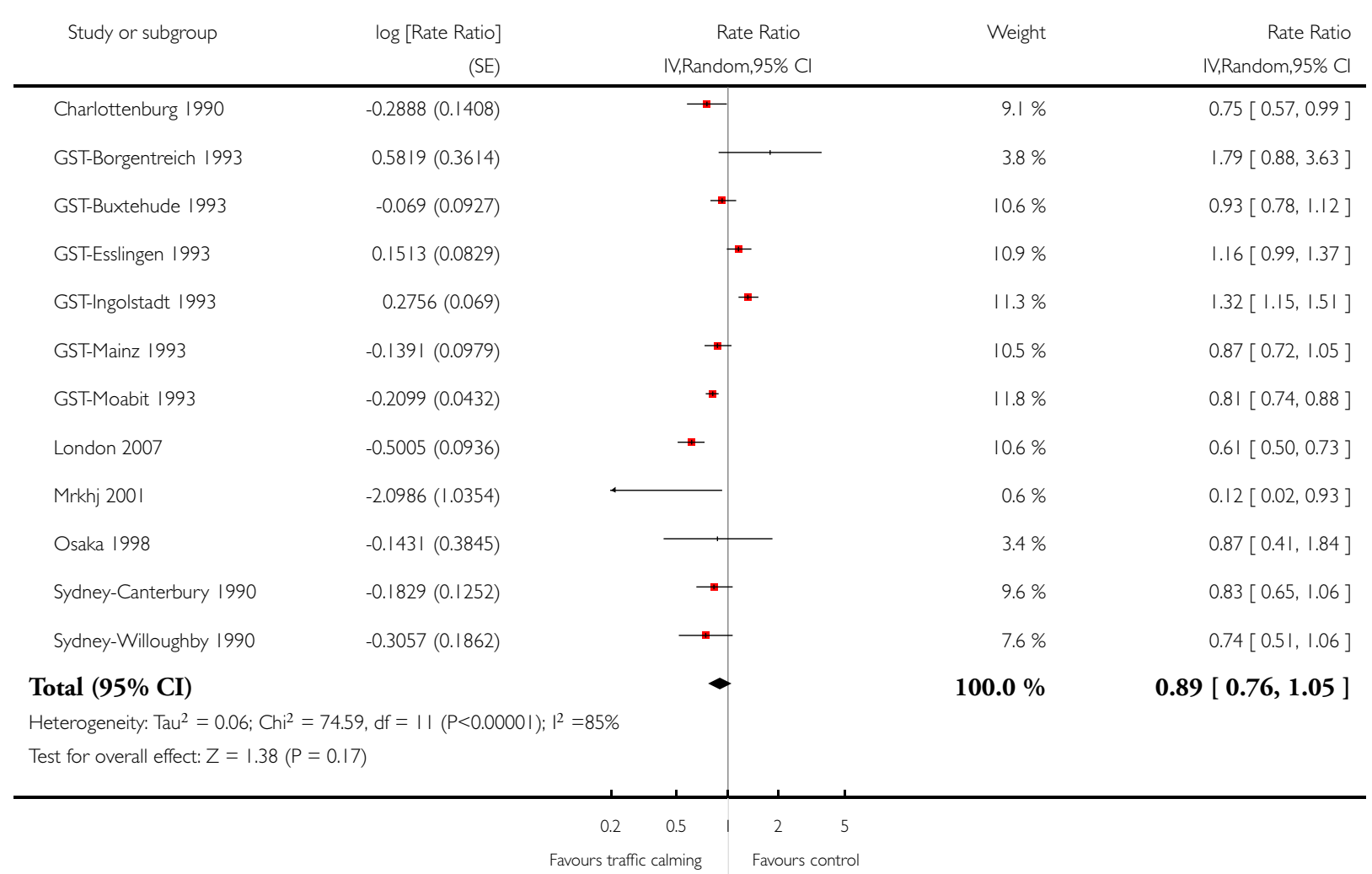




\section{Analysis I.4. Comparison I Area-wide traffic calming versus control, Outcome 4 Pedestrian-motor vehicle collisions.}

Review: Area-wide traffic calming for preventing traffic related injuries

Comparison: I Area-wide traffic calming versus control

Outcome: 4 Pedestrian-motor vehicle collisions

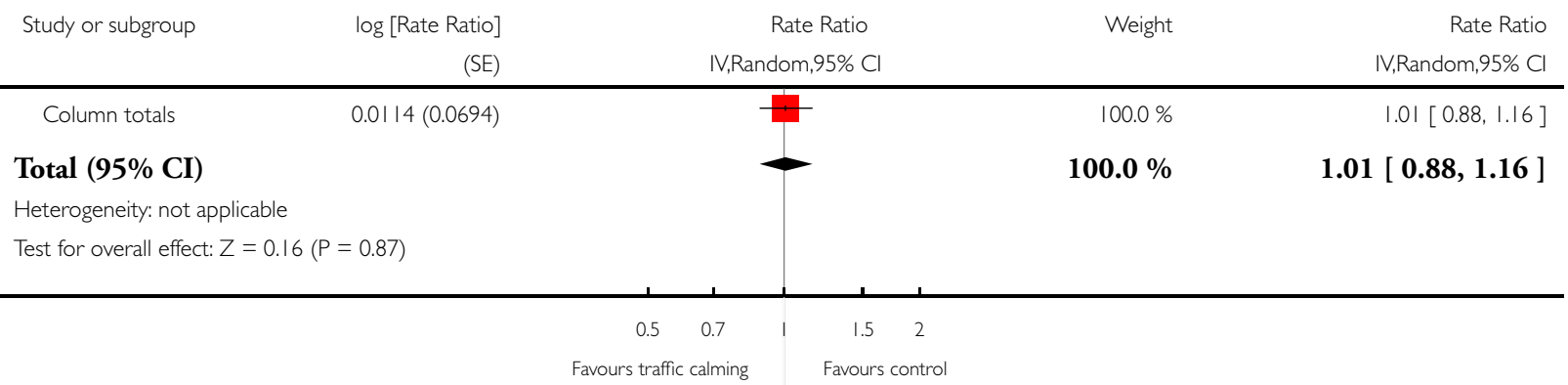

\section{A P PENDICES}

\section{Appendix I. MEDLINE \& EMBASE search strategy}

1. traffic restrain $\$$.ab,ti.

2. traffic calm\$.ab,ti.

3. traffic engineering.ab,ti.

4. road design \$.ab,ti.

5. road layout.ab,ti.

6. local traffic control.ab,ti.

7. traffic distribution.ab,ti.

8. speed cushion $\$ . a b, t i$.

9. speed hump\$.ab,ti.

10. speed bump\$.ab,ti.

11. speed table $\$ . a b, t i$.

12. vehicle speed control\$.ab,ti.

13. road narrowing.ab,ti.

14. road hierarchy.ab,ti.

15. left turn lane\$.ab,ti.

16. (“20" adj4 zone\$).ab,ti.

17. (“30” adj4 zone\$).ab,ti.

18. or/1-17

19. (Prospective adj1 (study or studies)).mp. [mp=title, original title, abstract, name of substance word, subject heading word]

20. (Program evaluation or evaluation research).mp. [mp=title, original title, abstract, name of substance word, subject heading word]

21. (randomi $\$$ or randomly).mp. [mp=title, original title, abstract, name of substance word, subject heading word]

22. (controlled adj2 (trial or trials or study or studies or experiment\$)).mp. [mp=title, original title, abstract, name of substance word, subject heading word]

23. (before adj1 after).ab,ti.

24. (control adj1 group\$).ab,ti.

25. (intervention adj1 group\$).ab,ti.

26. (experimental adj1 group $\$)$.ab,ti. 


\section{Appendix 2. TRANSPORT search strategy}

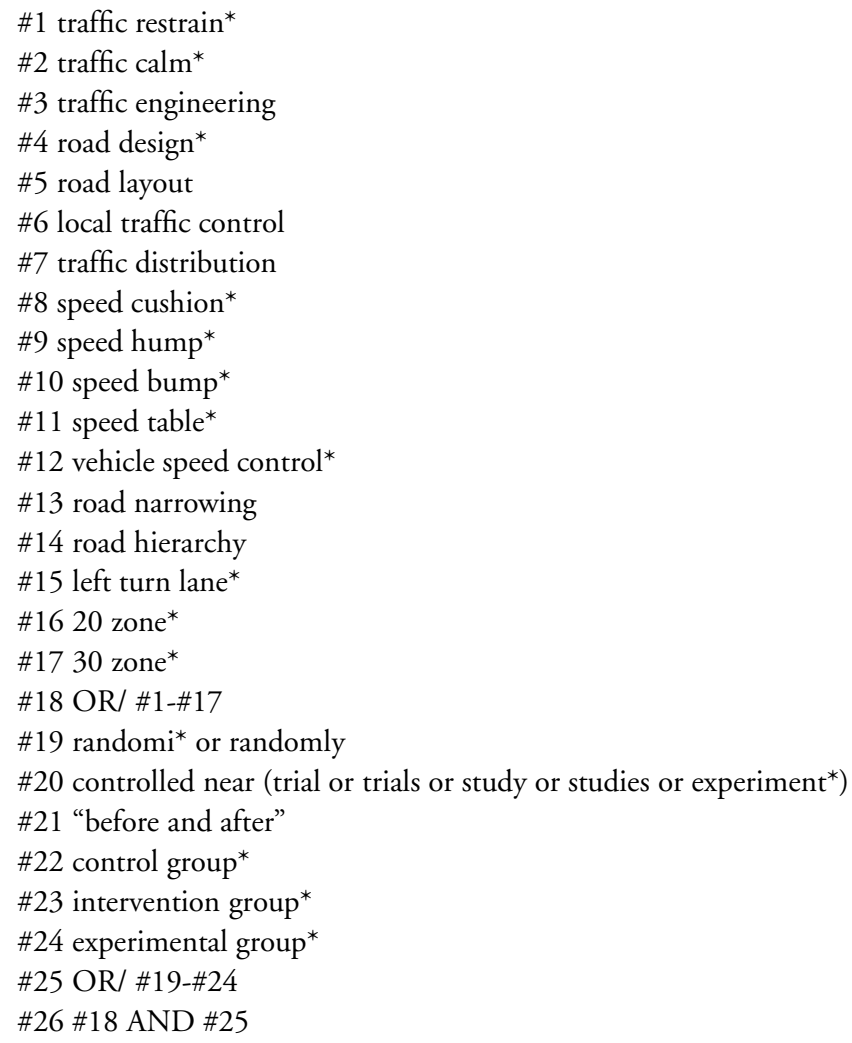

\section{Appendix 3. CENTRAL search strategy}

\#1 traffic next restrain*

$\# 2$ traffic next calm*

\#3 traffic next engineering

\#4 road next design*

\#5 road next layout

\#6 "local traffic control"

\#7 traffic next distribution

\#8 speed next cushion*

\#9 speed next hump*

\#10 speed next bump*

\#11 speed next table*

\#12 “vehicle speed control*”

\#13 road next narrowing

\#14 road next hierarchy

\#15 "left turn lane*"

\#16 20 next zone*

\#17 30 next zone*

\#18 or/1-17 


\section{Appendix 4. National Research Register search strategy}

(traffic next restrain*) or (traffic next calm*) or (traffic next engineering) or (road next design*) or (road next layout) or (local traffic control) or (traffic next distribution) or (speed next cushion*) or (speed next hump*) or (speed next bump*) or (speed next table*) or (vehicle speed control) or (road next narrowing) or (road next hierarchy) or (left turn lane) or (20 next zone*) or (30 next zone*)

\section{Appendix 5. International Bibliography of the Social Sciences}

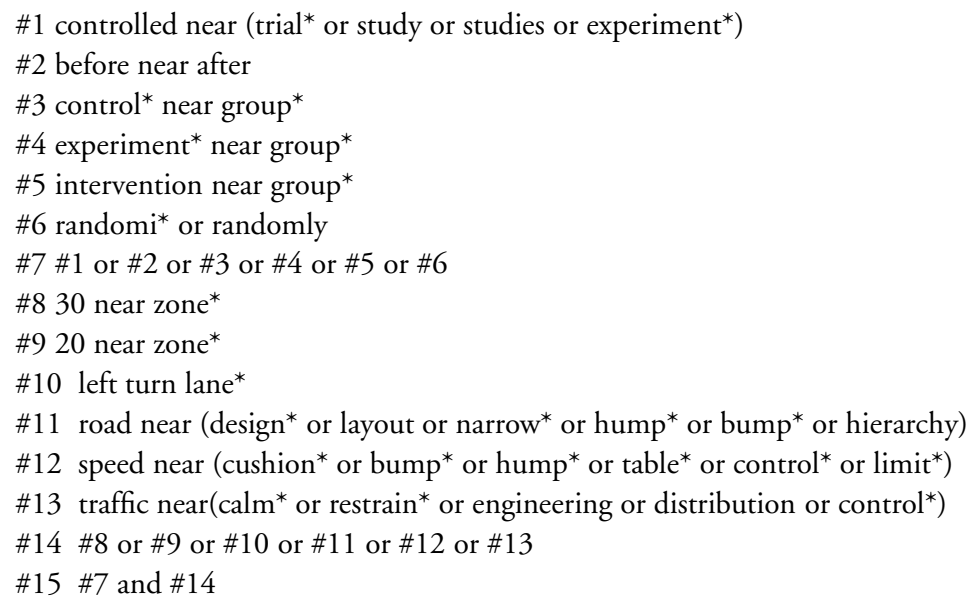

\section{WHAT'S NEW}

Last assessed as up-to-date: 31 December 2007.

\begin{tabular}{|l|l|}
29 April 2009 New search has been performed & $\begin{array}{l}\text { The review has been updated with the inclusion of a further six studies, based on } \\
\text { searches conducted to January } 2008 .\end{array}$ \\
& $\begin{array}{l}\text { The inclusion criteria have been amended to include reduced 'speed limit zones' } \\
\text { as eligible types of interventions. } \\
\text { RS contributed to the update of this version of the review. }\end{array}$ \\
\hline
\end{tabular}

\section{H I S T O R Y}

Protocol first published: Issue 2, 2001

Review first published: Issue 1, 2003

23 September 2008 Amended Converted to new review format. 


\section{CONTRIBUTIONS OFAUTHORS}

2003 review: FB helped to design the protocol, screened search records, obtained reports, extracted data and wrote the review. IR helped to design the protocol and write the review. TC performed the analyses and commented on the review. CF advised on the analyses and commented on the review. KK extracted data and helped to obtain reports. RW designed the search strategy and helped to design the protocol.

2008 update: RS screened search records, obtained reports, extracted data, updated the analyses and updated the review text. KK extracted data, helped update the analyses and update the review text. TC advised on the data analysis. FB advised on all aspects of the update and commented on the draft updated review.

\section{DECLARATIONS OF INTEREST}

None known.

\section{SOURCES OF SUPPORT}

\section{Internal sources}

- London School of Hygiene \& Tropical Medicine, UK.

- University of Hertfordshire, UK.

\section{External sources}

- Medical Research Council, UK.

- Transport for London, UK.

\section{NDEX TERMS}

\section{Medical Subject Headings (MeSH)}

Accident Prevention; Accidents, Traffic [mortality; ${ }^{*}$ prevention \& control]; Automobile Driving; Controlled Clinical Trials as Topic; Safety; Urban Health; Wounds and Injuries [epidemiology; prevention \& control]

\section{MeSH check words}

Humans 